\title{
APORTES DEl MODELO DE DisidenCIAS JUdiCIALES al Sistema Político. Pluralismo Judicial y DEBATE DEMOCRÁTICO
}

\author{
SERGio VerdUGo R. ${ }^{* * *}$
}

RESUMEN: En el derecho comparado existen diferencias en torno a la posibilidad de que las disidencias judiciales y prevenciones existentes dentro de tribunales colegiados puedan o no ser publicadas y conocidas por la comunidad. Algunos sistemas siguen una tradición de secretismo, y otros de transparencia. Este trabajo analiza los beneficios que el sistema de disidencias produce para el sistema político, examinando cuál es el rol de los jueces dentro éste. Se explora el vínculo de este debate con una visión de legitimidad judicial basada en el accountability y menos relacionada con la profesionalización y jerarquía de la judicatura. Se propone un marco para discutir el problema de la transparencia judicial dentro de aquellos países que han aceptado la existencia de una democracia (con justicia) constitucional, ofreciendo una línea de investigación y abriendo perspectivas para trabajos futuros.

PALABRAS CLAVE: Disidencia - voto particular - justicia constitucional - transparencia judicial - legitimidad judicial.

\section{CONTRIBUTIONS OF THE JUdiCIAL DisSENT MODEL TO THE POlitical SYSTEM. JUdicial PluRalism AND DEMOCRATIC DEBATE}

ABSTRACT: In a comparative law perspective there are differences related to the possibility of publishing the dissenting opinions and concurrences that exist inside collegiate courts. Some systems follow a

* Máster en Derecho, Universidad de California, Berkeley. Magíster en Derecho Público, P. Universidad Católica de Chile. Abogado. Licenciado en Ciencias Jurídicas, Universidad del Desarrollo. Profesor de Derecho Constitucional e investigador del Centro de Justicia Constitucional de la Universidad del Desarrollo. Correo electrónico: sverdugor@udd.cl. Fecha de recepción: 28 de julio de 2011

Fecha de aprobación: 11 de noviembre de 2011.

** Todos los textos citados cuyos originales se encuentran en inglés, fueron traducidos por el autor de este mismo artículo. Agradezco las conversaciones con el profesor Robert A. Kagan, sin las cuales este trabajo no habría sido posible. Además, agradezco los comentarios de José Manuel Díaz de Valdés, Nicolás Enteiche e Ignacio Covarrubias, y la colaboración del ayudante de la Dirección de Investigación de la Universidad del Desarrollo, Nicolás Galli. 
tradition of secrecy, while others follow transparency. This work analyzes the benefits that the dissenting opinion system produces for the political system, studying the role of the judges inside it. It explores the relation between this debate and a perspective of judicial legitimacy based on accountability and less related to the professionalization and hierarchy of the judicature. The paper proposes a framework for discussing the problem of judicial transparency inside those countries that accept constitutional democracy and judicial review, offering a line of research and opening perspectives for future papers.

KEY WORDS: Dissent - separate vote - constitutional power judicial transparency - judicial legitimacy.

\section{INTRODUCCIÓN}

Este trabajo aborda el problema del voto disidente (particular, de minoría) dentro del sistema judicial de los tribunales colegiados. En particular, me centraré en la siguiente pregunta: ¿son saludables para el sistema legal y democrático los votos de minoría expresados en sentencias judiciales ${ }^{1}$ ?

Como se verá más adelante, distintas tradiciones legales entregan respuestas diversas a esta pregunta, generando un interesante debate entre ciertos actores del mundo académico y judicial. Un primer sistema, presente en la mayoría de los países del derecho europeo continental (en adelante, los países del "derecho civil"), prefiere la adopción de un régimen de secretismo, donde las sentencias se muestran siempre como unánimes y las posibles opiniones minoritarias no son publicadas. Es un sistema de unanimidad forzada ${ }^{2}$.

$1 \quad$ El sistema de disidencias judiciales, para los efectos de este trabajo, comprende los votos de minoría y las prevenciones o votos concurrentes que se suman a la mayoría señalando una diferencia argumentativa. Ambas marcan una diferencia con la mayoría, aun cuando el voto de prevención sea, en el resultado final, sumado numéricamente a la sentencia. Ambas son parte del debate jurídico y, en ciertos casos, político. Como Antonin Scalia señala, ambos (la disidencia y la prevención) se encuentran en la minoría de la Corte. "Al hablar de opiniones disidentes, me refiero a aquellas opiniones que difieren del razonamiento de la Corte". SCALIA (1994) 33. Hay poca diferencia entre las disidencias y prevenciones "(...) en la medida que el atractivo de la opinión separada consiste en que las opiniones legales son importantes, después de todo, por las razones que ellas entregan, y no por los resultados que ellas anuncian; los resultados pueden anunciarse en sentencias u órdenes sin opinión alguna (...) entregar las razones equivocadas es entregar todo erróneo, y eso vale una disidencia, aun cuando a esa disidencia se le llame prevención”. SCALIA (1994) 33.

2 Algunos ejemplos de Europa continental que tienen sistemas de unanimidad forzada: Francia, Italia, Grecia, Dinamarca, Rusia, Bélgica, Luxemburgo y Holanda. Suecia y Finlandia son excepciones. Nadelmann, Kurt H. (1959). "The Judicial Dissent. Publication v. Secrecy". The American Journal of Comparative Law, vol. 8: pp. 413, así como también Portugal. 
Un segundo modelo, existente en algunas cortes internacionales, en los países del derecho anglosajón ${ }^{3}$ y en algunos del derecho civil (especialmente los latinoamericanos ${ }^{4}$ ), consiste en la adopción de una regla de transparencia donde la unanimidad judicial solo puede lograrse si todos los jueces que integran un mismo tribunal coinciden en fallar de una misma manera. Este sistema de transparencia se caracteriza por la publicación de los votos de minoría cuando existen opiniones particulares que controvierten la visión mayoritaria ${ }^{5}$, permitiendo a los disidentes la libre expresión de sus ideas y opiniones jurídico-constitucionales.

En este trabajo no examinaré el debate acerca de si existe o no una protección constitucional (como libertad de expresión, si se quiere) a la disidencia judicial ${ }^{6}$; y tampoco revisaré las razones que algunos académicos han entregado para explicar por qué los jueces disienten ${ }^{7}$. En

Nadelmann (1959) 421. Además, Alemania y España cuentan con un sistema muy limitado de disidencias, normalmente asociado a casos constitucionales. En el caso de España, los votos particulares se encuentran expresamente autorizados por la Constitución de 1978, en su art. 164.1. Austria y Portugal permiten a sus Tribunales Constitucionales la publicación de disidencias. Islandia, por su parte, puede ser considerado como poseedor de un sistema mixto, donde la doctrina del precedente (stare decisis) juega un rol importante en la configuración del Derecho, lo que presiona por la utilización más frecuente de la disidencia.

Algunos ejemplos asiáticos que recogen la tradición europea continental de secretismo judicial son China, Líbano e Indonesia. Hay otros países asiáticos que, sin perjuicio de contar con raíces del derecho civil, han permitido excepcionalmente la introducción de disidencias de manera muy restringida, como ocurre con Corea del Sur y Japón. Nadelmann (1959) 422.

3 Véanse, por ejemplo, los casos de Inglaterra, Irlanda, Escocia, India, Estados Unidos, Canadá, Australia, Nueva Zelandia, Pakistán, Filipinas y Sudáfrica.

4 Por ejemplo, véanse las sentencias de los tribunales superiores y colegiados de México, Chile, Colombia, Perú, Uruguay, Argentina y Brasil. En Haití y República Dominicana, sin embargo, se sigue la tradición del secretismo francés.

5 Parece estar enraizado en la cultura jurídica del derecho civil, el considerar erróneo hablar de una opinión judicial de mayoría. Se estima que el voto de mayoría es, en sí mismo, la sentencia, por lo que se prefiere utilizar simplemente la voz sentencia, o fallo. Lo anterior denota una visión donde se entiende que solo existe una opinión jurídica válida dentro del Estado de Derecho, quitándole valor a los votos particulares. En este trabajo, a pesar de la opinión de quienes pertenecen a la cultura jurídica descrita, utilizaré las voces mayoría, voto de mayoría o sentencia de mayoría con el objeto de simplificar las explicaciones que entregaré.

$6 \quad$ En los EE.UU. existe una discusión acerca de si existe o no un derecho a proporcionar opiniones disidentes. Véase, por ejemplo, a Brennan (1986) 437-438. y LitTle, Rory (1999). "Reading Justice Brennan: Is There a "Right" to Dissent?". Hastings Law Journal, vol. 50, pp. 683-704. Esta discusión también se ha presentado en otros lugares, como Australia. Véase Lynch, Andrew (2004). "Is Judicial Dissent Constitutionally Protected?". Macquarie Law Journal, vol. 4, pp. 81-104.

7 En efecto, considerando que la disidencia es (o puede ser) costosa para los jueces, ya que (a) ella implica mayor trabajo (investigar y redactar), (b) sin observar resultados prácticos inmediatos, (c) asumiendo una pérdida en el debate, (d) perteneciendo a una posición minoritaria, (e) posiblemente generando enemistades con los jueces de la mayoría, etc., algunos se han preguntado por qué algunos jueces igualmente redactan disidencias, especialmente desde la perspectiva (directa o indirecta) del análisis económico del Derecho. Para ver esta materia, revísese a Peterson, Steven A. (1981). "Dissent in American Courts". The Journal of Politics, vol. 43, No 2: pp. 413-425.; Lynch, Andrew (2004-A). "Taking Delight in Being 
cambio, me centraré en el análisis de las virtudes y defectos que la regla de transparencia y secretismo significan para el Estado democrático de Derecho.

Argumentaré que el sistema de disidencias judiciales fortalece la transparencia del sistema legal, entregando un grado de certeza acerca del comportamiento futuro de los jueces (y, desde luego, de los tribunales que estos integran) que permite seguir de manera más acertada la evolución del Derecho por parte de la comunidad. Además, sugeriré que la regla de transparencia favorece la calidad de las sentencias judiciales y el debate jurídico, creando un efecto-denuncia (whistleblower effect) que estimula la adopción de posiciones moderadas por parte de una mayoría de jueces que, en definitiva, serán quienes concurran a la sentencia final. Lo anterior representa un efecto saludable para que la doctrina jurídica que se defiende mediante la sentencia no se aleje demasiado de las diferentes posiciones existentes en el debate público y en el sistema político y, además, para que las opiniones de la mayoría se adapten mejor a Derecho. Estos argumentos cobran fuerza especialmente tratándose de sentencias en materia constitucional.

Las ideas que defenderé necesitan ser ponderadas con las razones que se han entregado para favorecer algún tipo de regla de unanimidad forzada. Así, es necesario examinar las virtudes y defectos de la ilusión de unidad judicial que el sistema de secretismo entrega, el que (como se verá) se asocia a una concepción reducida del rol de los jueces dentro del sistema político. ¿Contribuye esta unanimidad artificial a fortalecer la legitimidad de las cortes? ¿Es útil para que los tribunales puedan enfrentar de mejor manera la excesiva carga de trabajo que tienen? ¿Sirve para eludir el problema de la animosidad entre jueces de un mismo tribunal?

Mostraré que algunas de estas razones son parcialmente verdaderas, y que otras son simples objeciones a la regla de transparencia que pueden ser controladas. En definitiva, y considerando que la adopción de un sistema u otro (ya sea de transparencia o de secretismo) se vincula con la visión que los sistemas legales en particular tienen acerca del rol de sus jueces dentro del sistema constitucional, sugeriré que si lo que se desea es avanzar hacia un constitucionalismo moderno (con control judicial constitucional de verdad), entonces conviene adoptar un sistema donde las disidencias sean publicadas. Asimismo, sugeriré que la adopción de la regla de transparencia, si bien no necesariamente convierte a los jueces en parte

Contrary, Worried about Being a Loner or Simply Indifferent: How do Judges really feel about Dissent?". Federal Law Review, vol. 32, pp. 311-329; Posner, Richard (2008) How Judges Think. $1^{a}$ edición. Harvard, Boston: Harvard University Press, pp. 32-34 y p. 51; EpsteIn, Lee, Landes, William M. and Posner, Richard A. (2010). "Why (and When) Judges Dissent: A Theoretical and Empirical Analysis". U of Chicago Law \& Economics, Olin Working Paper No. 510. Disponible en: http://ssrn.com/abstract $=1542834$ 
activa del debate público y social, fortalece la democracia y el mercado de las ideas, especialmente cuando dicha regla se adopta en tribunales facultados para fallar utilizando la Constitución.

El propósito de lo anterior es proponer las siguientes ideas: (a) los países del derecho civil que aún no han adoptado un sistema de disidencias judiciales (como Francia, Italia, Rusia, China e Indonesia, por ejemplo), debieran comenzar a estudiar el posible impacto que ello produciría en su interior, considerando las particularidades propias de su sistema legal y político; (b) que los sistemas de derecho civil que han implementado de manera parcial (y tímida) una regla de transparencia (como Alemania, Espańa y Japón, por ejemplo) debieran estudiar la posibilidad de profundizar la misma; y (c) que los países del derecho civil que ya cuentan con un sistema de voto de minoría (como Chile y México, por ejemplo), debieran incorporar en sus investigaciones un cuestionamiento al rol que los jueces constitucionales cumplen dentro del sistema político y del debate público. Asimismo, debieran revisar aquellas posiciones donde se asume una visión reducida de la función judicial propia de la mayoría de los países del derecho continental europeo, particularmente el francés.

Como el problema de las disidencias está asociado a características propias de las tradiciones legales, puede surgir una objeción de derecho comparado, mediante la cual no correspondería proponer la importación de instituciones extranjeras (especialmente las del derecho anglosajón) sin antes considerar las diferencias estructurales que los diversos sistemas jurídicos contienen. Este punto, al que dedicaré un apartado especial, debe considerar a los sistemas jurídicos como procesos que evolucionan y no como modelos estáticos y rígidos. Así, procesos como la constitucionalización del ordenamiento jurídico y el creciente influjo del Derecho Internacional han significado cambios relevantes que deben tomarse en cuenta a la hora de proponer cambios dentro de un sistema legal.

Seguiré el siguiente orden: en primer lugar (1), describiré el sistema de opiniones judiciales en general, considerando brevemente las principales diferencias entre las diversas tradiciones jurídicas y distinguiendo las maneras en que la regla de transparencia puede implementarse. En segundo lugar (2), reproduciré y analizaré las virtudes que se han invocado para defender la regla de secretismo y unanimidad forzada. En tercer lugar (3), revisaré las virtudes que algunos académicos y jueces (especialmente norteamericanos) han utilizado para defender la publicidad del voto disidente. En cuarto lugar (4), comentaré brevemente lo que algunos han denominado abuso de la disidencia, sugiriendo que una tasa excesiva de disidencias no disminuye necesariamente los efectos saludables de la transparencia judicial. Finalmente (5), sugeriré algunas conclusiones generales, ofreciendo un marco teórico para continuar con la discusión y con posibles investigaciones futuras. 


\section{1) EL SISTEMA DE OPINIONES JUDICIALES Y LAS TRADICIONES LEGALES: LA OBJECIÓN DEL DERECHO COMPARADO}

En general, las maneras de eliminar las prácticas disidentes de los jueces pertenecientes a una minoría dentro de un tribunal, pueden adoptar dos formas: (a) que la Corte adopte de manera voluntaria seguir una regla de unanimidad como práctica judicial, o (b) que el sistema legal prohíba publicar los votos particulares, considerando la deliberación interna del tribunal como una discusión secreta.

Un ejemplo del primer caso (a), lo encontramos en la experiencia del segundo período de la Suprema Corte de los EE.UU., donde el presidente de la Corte (el Chief Justice), el juez Marshall, condujo a la misma a la adopción voluntaria de la regla de unanimidad. De esta manera, la Suprema Corte se apartó de la antigua tradición inglesa mediante la cual cada uno de los jueces de un tribunal colegiado fallaba de manera individual (aun cuando todos coincidieran en el mismo fallo). En el ejemplo de la Corte Marshall, todos sus jueces acordaron la regla de unanimidad de manera estratégica, como una manera de fortalecer el poder político de la Corte ${ }^{8}$. La norma de consenso no se basaba, entonces, en un requerimiento de la tradición legal (la tradición anglosajona dicta todo lo contrario), por lo que la posibilidad de cambiar la manera de presentar los votos de las sentencias judiciales probablemente nunca se perdió. De hecho, hoy la Suprema Corte norteamericana se caracteriza, entre otras cosas, por la cantidad de visiones contrapuestas que son publicadas dentro de las mismas sentencias.

El interés de este trabajo se relaciona mayormente con la segunda manera (b) de lograr la norma de consenso: a través de la unanimidad forzada, donde el sistema no permite expresar disidencias de una manera formal (dentro del mismo documento que contiene la sentencia). En este caso, la tradición legal prefiere mostrar una sola respuesta judicial (la de la mayoría), la única que es considerada como consistente con el Derecho, aun cuando puedan existir jueces disidentes (cuyos votos se ocultan a la comunidad y a las partes). En este sistema, los jueces no están obligados a fallar de manera unánime (como ocurre normalmente con la regla de

$8 \quad$ Véase, por ejemplo, Rehnquist, William H. (1966). "The Supreme Court: The First Hundred Years Were the Hardest". University of Miami Law Review, vol. 42, pp. 475-490 y BenNetT, Robert W. (1991). "A Dissent on Dissent". Judicature, vol. 74; No 5, pp. 258., quien explica de qué manera la unanimidad de la Corte Marshall fue utilizada con un fuerte sentido de misión institucional. Sin embargo, existe una visión alternativa de la historia constitucional norteamericana, por la cual la regla de unanimidad de la Corte Marshall se habría logrado gracias a la naturaleza de los casos que llegaban al conocimiento de la Corte de esa época: habrían sido casos fáciles (easy cases). Véase Epstein, Lee, Segal, Jeffrey and Spaeth, Harold J. (2001). "The Norm of Consensus of the U.S. Supreme Court". American Journal of Political Science, vol. 45, pp. 362-377. 
jurado), sino que solo están obligados a mostrar lo que opina la mayoría y a guardar secreto acerca de lo que opina la minoría. En general, como ya se dijo, la tradición del secretismo se asocia a los países del derecho civil europeo continental (y también en los países asiáticos ${ }^{9}$ ), y la tradición de la transparencia a los países del derecho anglosajón (véase la lista de países en las notas al pie de la introducción) ${ }^{10}$, con varias excepciones y matices que ya enuncié ${ }^{11}$. Uno de esos matices, por ejemplo, consiste en que Alemania y España han desarrollado un sistema de votos particulares limitado a sus Cortes Constitucionales ${ }^{12}$. Sin embargo, en la influyente tradición del derecho continental europeo, no es raro encontrar jueces que publican trabajos académicos donde se muestran críticos con una

9 Los países asiáticos han recibido la herencia continental europea (con algunas excepciones como India), por lo que en general cuentan con un sistema de secretismo. Sin embargo, las causas del secretismo también pueden asociarse a otros factores. Como dice un comparativista, en el caso de la tradición jurídica asiática, en general, es muy difícil encontrar disidencia en el pensamiento jurídico. Glenn, H. Patrick (2007) Legal Traditions of the World. $3^{\mathrm{a}}$ edición. New York: Oxford University Press, pp. 328. Si no hay visiones minoritarias, entonces mal pueden existir disidencias. Probablemente este fenómeno se asocia a una cultura donde existe poca (o nula) disidencia dentro del sistema político (como China) o probablemente una sociedad con bajos niveles de bajos niveles de conflicto o litigio (como Japón).

10 Merryman, John Henry and Pérez-Perdomo, Rogelio (2007) The Civil Law Tradition. An Introduction to the Legal Systems of Europe and Latin America. $3^{\text {a }}$ edición. Stanford, California: Stanford University Press, pp. 122. Véase un buen ejercicio comparado de estilo judicial en Goutal, Jean Louis (1976). "Characteristics of Judicial Style in France, Britain and the U.S.A.". The American Journal of Comparative Law, vol. 24, pp. 43-72., quien intenta conectar la "civilización legal" de un país con la manera en que los jueces motivan sus decisiones, estudiando los ejemplos de Francia, Inglaterra y EE.UU. Como la existencia de decisiones minoritarias separadas se relaciona con la manera en que las decisiones judiciales son tomadas, es importante distinguir el clásico modelo de razonamiento deductivo que utilizan los jueces del derecho civil, con el razonamiento orientado a los hechos que se utiliza en la tradición anglosajona. Existe una diferencia importante en la argumentación legal: los jueces anglosajones utilizan precedentes obligatorios que exigen el análisis de analogía entre los casos que se presentan, mientras los jueces del derecho civil argumentan sobre la base de leyes y principios. Además, la extensión de las decisiones judiciales es muy diferente, siendo en general más cortas en el derecho civil: "una sentencia francesa de quince líneas no es nada inusual”. Goutal (1976) 56. Como puede verse, la tradición judicial del derecho civil no tiene mucho que ver con lo que ocurre, por ejemplo, en el Tribunal Constitucional Chileno, donde las sentencias suelen ser bastante largas, donde se citan casos previos y donde las disidencias son muy frecuentes. Véase una buena comparación de las tradiciones legales y las causas que explican sus diferencias en Fernández Segado, Francisco (2009). "La Recepción del Sondervotum en Alemania". Revista Iberoamericana de Derecho Procesal Constitucional, No 12, pp. 77-83.

11 Para un útil análisis del problema de la transparencia judicial como tema general, véase la comparación entre la Suprema Corte de los EE.UU. y la Corte de Casación francesa, que realiza Lasser, Michel (2004) Judicial Deliberations. A Comparative Analysis of Judicial Transparency and Legitimacy. 1a edición. New York: Oxford University Press, pp. 382

12 Además, véase a Amram, Philip W. (1957). "The Dissenting Opinion Comes to the German Courts". The American Journal of Comparative Law, vol. 6, No 1, pp. 108-111, quien comenta una sentencia de una Corte Suprema estatal alemana, que rompe con la regla de unanimidad en un caso muy político. Véase también a FernáNdez (2009) 99-109. 
sentencia que no comparten ${ }^{13}$. A estos trabajos, se suman las opiniones de otros actores relevantes que participan del debate judicial ${ }^{14}$. Lo anterior, si bien permite relativizar la ilusión de la unanimidad forzada, no es un remedio para el secretismo judicial.

Resulta muy interesante observar cómo operan los votos disidentes en los países latinoamericanos, los que pese a adoptar una tradición del derecho civil, admiten una regla de transparencia, especialmente para sus cortes superiores y sus tribunales constitucionales. Este es el caso, a lo menos, de México, Brasil, Chile, Argentina, Colombia, Ecuador, Uruguay y Perú ${ }^{15,16}$

El sistema de disidencias ha sido ampliamente estudiado en los países de tradición anglosajona, aunque en los países del derecho civil la discusión también existe. Por ejemplo, en Italia ${ }^{17}$, Alemania ${ }^{18}$ y España ${ }^{19}$, la regla de unanimidad forzada ha sido criticada por algunos. Sin embargo, parece ser que dicho problema ha generado muy pocos trabajos académi$\cos ^{20}$, sin perjuicio de la existencia de comentarios aislados ${ }^{21}$. Por lo an-

13 Merryman (2007) 122-123. Algunos ejemplos de este comportamiento puede verse en algunos jueces franceses. Véase Cappelletti Mauro, Merryman, John Henry, Perillo, Joseph M. (1965). The Italian Legal System. 1a edición. Stanford, California: Stanford University Press, pp.118.

14 Por ejemplo, y como Loth recuerda, en Francia “(...) además del oficial retrato de las decisiones judiciales, un discurso no oficial que es constituido por la opinión del Abogado-General (Advocate-General), las anotaciones de académicos jurídicos, y los reportes de los magistrados informantes. Aunque los resultados de este discurso no siempre son publicados -hoy son debatidos en audiencias públicas- es aquí donde la discusión real tiene lugar". Loтн, Marc A (2009) "Courts in a Quest for Legitimacy: a Comparative Approach". En Huls, Nick, Adams, Maurice, y Bомноғғ, Jacco (editores): The Legitimacy of Highest Courts' Rulings. Judicial Deliberation and Beyond. $1^{a}$ edición. New York: Cambridge University Press, pp. 270.

15 Algunas excepciones pueden ser encontradas en países centroamericanos que siguen fuertemente la tradición francesa, como ocurre con Haití y República Dominicana. NAdelmanN (1959) 421. Fuera de Centroamérica, es posible encontrar otros países que se encuentran en la misma situación, como Egipto y el Líbano.

16 Otro caso interesante es el del Estado de Luisiana, el que cuenta con dos tradiciones jurídicas coexistentes: la del derecho civil a nivel estatal (debido a la influencia francesa), y la anglosajona a nivel federal. Hoy, en general, Luisiana admite el modelo de disidencias judiciales a ambos niveles, aunque antiguamente no era así. Véanse algunas reflexiones acerca de esto en Sanders, Joe W. (1963). "The Role of Dissenting Opinions in Louisiana". Louisiana Law Review, vol. 23, pp. 673-679, quien favorece el uso de disidencias en el sistema del derecho civil. En Luisiana, la publicación de las opiniones disidentes estaba prohibida en la Constitución de 1898, y se permitió recién bajo la Constitución de 1921. SANDERs (1963) 678.

17 Cappelletti (1965) 130 y 163.

18 Véase un buen resumen de la discusión alemana en Fernández (2009).

19 Medina Rubio, Ricardo (2000) "La discrepancia en el seno del Tribunal Constitucional". Corts: Anuario de Derecho Parlamentario, Nº 9: pp. 305-306; CÁmara Villar, Gregorio (1993). Votos particulares y derechos fundamentales en la práctica del Tribunal Constitucional Español: 1981-199. Madrid: Ministerio de Justicia, pp. 450.

20 Véase, por ejemplo, el trabajo ya citado de Fernández (2009) y los otros trabajos que el mismo autor utiliza como fuente.

21 Por ejemplo, véase un breve comentario de Dominique Rousseau, quien rechaza la idea de tener un sistema de disidencias Rousseau, Dominique (2002) La Justicia Constitucional en 
terior, es consecuencia forzosa revisar los trabajos de autores anglosajones, quienes han prestado mayor atención a esta materia. El problema es que todos ellos pertenecen a una tradición legal que considera la disidencia como parte elemental del desarrollo del ordenamiento jurídico. En efecto, "[e]l common law aprecia a sus disidentes. Ellos son mantenidos vivos en las opiniones disidentes como reglas de la 'minoría' que sobreviven en una parte de las muchas jurisdicciones que conforman el common law"22. Es más, en la tradición norteamericana las opiniones disidentes son consideradas como parte del sistema jurídico. Así, no resulta extraño que numerosos académicos norteamericanos ${ }^{23}$, y algunos importantes jueces ${ }^{24}$,

Europa. 2a edición. Madrid: Centro de Estudios Políticos y Constitucionales, pp. 50. En una posición contraria, y contestando directamente al profesor Rousseau, véase NogueirA Alcalá, Humberto (2005) "La Integración y el Estatuto Jurídico del Tribunal Constitucional después de la Reforma Constitucional de 2005", Foro Constitucional Iberoamericano, No 11: pp. 147-148. Además, véase una breve defensa de los votos particulares en el trabajo de Peter Häberle. HäBerLe, Peter (2001). "La Jurisdicción Constitucional institucionalizada en el Estado constitucional". Anuario iberoamericano de justicia constitucional, No 5, pp. 180. A mayor abundamiento, véase PinNA, Andrea (2009) "Filtering Applications, Number of Judgments delivered and Judicial Discourse by Supreme Courts: Some Thoughts Based on the French Example". En Huls, Nick, Adams, Maurice, y Bомноғf, Jacco (editores): The Legitimacy of Highest Courts' Rulings. Judicial Deliberation and Beyond. 1 ${ }^{\text {a }}$ edición. New York: Cambridge University Press, pp. 175-187 у Lотн (2009) 270-271.

22 Fletcher, George P., Sheppard, Steve (2005) American Law in a Global Context. $1^{\text {a }}$ edición. New York: Oxford University Press, pp. 173. En efecto, los norteamericanos estiman y valoran a sus disidentes. Existen buenos ejemplo en la literatura disponible, donde varios autores han dedicado libros enteros a jueces que fueron famosos disidentes: (1) un libro de Tinsley E. Yarbrough llamado "John Marshall Harlan: great dissenter of the Warren Court". Yarbrough, Tinsley E. (1992) John Marshall Harlan: great dissenter of the Warren Court. $1^{\text {a }}$ edición. New York: Oxford University Press, pp. 395; (2) la publicación de una compilación de las disidencias de Antonin Scalia en Ring, Kevin A. (2004) Scalia Dissents: Writings of the Supreme Court's Wittiest, most Outspoken Justice. 1 1 edición. Washington DC: Regnery Publishing, Inc.; (3) un libro de Mark Tushnet sobre grandes opiniones disidentes en la historia de la Suprema Corte de los EE.UU., Tushnet, Mark V. (editor) (2008) I Dissent: great Opposing Opinions in Landmark Supreme Court Cases. $1^{\text {a }}$ edición. Boston: Beacon Press, pp. 229; y muchos libros que se han publicado en honor al juez Holmes, entre otros.

23 Véase, por ejemplo, la antigua y ya clásica opinión de un famoso decano de la Escuela de Derecho de Harvard, Pound, Roscoe (1953). "Cacoethes Dissentiendi: The Heated Judicial Dissent”. American Bar Association Journal, vol. 39, pp. 794-797. Además, véanse entre otros los trabajos de Nadelmann (1959) y Nadelmann, Kurt H. (1964). "Non-Disclosure of Dissents in Constitutional Courts: Italy and West Germany". The American Journal of Comparative Law, vol. 13, pp. 268-276; Cross, Frank B. AND Tiller, Emerson H. (1998). "Judicial Partisanship and Obedience to Legal Doctrine: Whistleblowing on the Federal Courts of Appeals". Yale Law Journal, vol. 107, pp. 2155-2176 y Sunstein, Cass (2005) Why Societies Need Dissent. 1a edición. Harvard, Boston: Harvard University Press, pp. 166-193. Véase una crítica a la práctica y abuso de la disidencia en la Suprema Corte de los EE.UU. en Bennett (1991).

24 Véanse, a modo de ejemplo, los comentarios publicados de algunos jueces de la Suprema Corte, como Cardozo (1939); Stone, Harlan F. (1943). "Dissenting Opinions are not Without Value". Journal of the American Judicature Society, vol. 26, pp. 78; Douglas, William O. (1948). "The Dissent: A Safeguard of Democracy". Journal of the American Judicature Society, vol. 32, pp. 104-107; Brennan (1986) y SCalia (1994). Además, véanse trabajos de 
favorezcan la publicación de los votos particulares. Estos son considerados como una parte crucial del Derecho, el que probablemente producirá efectos en el futuro. Por esta razón, por ejemplo, en el Derecho Constitucional norteamericano las disidencias son vistas como una "Constitución alternativa"25. Esta "Constitución alternativa" percibe a la minoría judicial como una voz contraria, una posible respuesta a una pregunta jurídica que persigue ser reconocida. No resulta extraño observar casos relevantes donde las disidencias se transforman en Derecho válido ${ }^{26}$.

La riqueza de la discusión norteamericana admite diferentes perspectivas. Algunos trabajos utilizan las disidencias para demostrar algunas hipótesis relativas al uso de elementos extra jurídicos (attitudinal studies) en procesos de decisión judicial (judicial decision making) ${ }^{27}$, y otros trabajos intentan defender o estudiar directamente el sistema de disidencia como tema central ${ }^{28}$. Sin embargo, muy pocos trabajos tienen un enfoque propio de derecho comparado $^{29}$, y la gran mayoría de ellos se enfocan en la práctica de tribunales norteamericanos.

Como en este trabajo sugeriré revisar las prácticas asociadas a la regla del secretismo que algunas tradiciones legales del derecho civil reconocen, es importante hacerse cargo de la objeción de derecho comparado. Dicha objeción consiste en que no corresponde proponer cambios a un sistema jurídico cuando dichas reformas provengan de una tradición diferente, especialmente si estas están relacionadas con un aspecto relevante de la cultura jurídica de un país. Por lo anterior, es aconsejable considerar las diferencias entre las diferentes tradiciones legales antes de proponer las reformas pertinentes.

otros jueces de relevancia, como Sanders (1963); Fletcher, William A. (2009) "Dissent". Golden Gate University Law Review, vol. 39, pp. 291-300 y Evans, Evans A. (1938). "The Dissenting Opinion. Its use and abuse". Missouri Law Review, vol. 3, pp. 120-142.

25 Fletcher (2005) 172-200.

26 Recuérdese el ejemplo de la famosa disidencia del juez John Marshall Harlan en Plessy $v$. Ferguson (163 U.S. 537-1896), donde se opuso a la aceptación de la doctrina "separados pero iguales" (separate but equal doctrine), que la Suprema Corte utilizaba para justificar diferencias en el trato que se proporcionaba a individuos de razas diferentes, especialmente la afroamericana. El caso Plessy, que acogió dicha doctrina, fue superado por el ya histórico caso Brown v. Board of Education (347 U.S. 483-1954), donde es posible inferir que la visión de Harlan comenzó a ser considerada como ley válida.

27 Véase, por ejemplo, a Pritchett, C. Herman (1941). "Divisions of Opinion Among Justices of the US Supreme Court, 1939-1941". The American Political Science Review, vol.35, pp. 890-898; Segal, Jeffrey A., Spaeth, Harold J. (1996). "The Influence of Stare Decisis on the Votes of United States Supreme Court Justices”. American Journal of Political Science, vol. 40, pp. 971-1003 y a Cross (1998).

28 Aquí hay algunos ejemplos: Pound (1953); Peterson (1981); Bennett (1991); Epstein (2001); Lynch (2004 A); Epstein (2010); Sunstein (2005) 166-193. Además, véase a Posner (2008) 32-34 y 51.

29 Véanse algunos ejemplos en Nadelmann (1959) (1964) y Lasser (2004). 
La objeción anterior será respondida desde dos perspectivas: en primer lugar (1.1), sosteneré que el secretismo no es esencial a la tradición del derecho civil; y en segundo lugar (1.2), reenfocaré la perspectiva que dicha objeción utiliza, comprobando que ella no excluye necesariamente la factibilidad de que el sistema de disidencia pueda operar en tradiciones aparentemente resistentes. En efecto, la objeción de derecho comparado tiende a observar a las tradiciones jurídicas como fenómenos estáticos y rígidos, en circunstancias que ellas se ven influenciadas por procesos que permanentemente están haciéndola evolucionar. De la intensidad de dichos procesos dependerá, en varias ocasiones, la posibilidad de que nuevos diseños institucionales tenga éxito o no. En particular, los fenómenos de la constitucionalización y la internacionalización del Derecho, abren más espacios a acoger una regla de transparencia que admita disidencias judiciales en los países del derecho civil, como explicaré.

\section{(1.1) EL SECRETISMO NO ES ESENCIAL A LA TRADICIÓN DEL DERECHO CIVIL}

Existe una larga lista de países pertenecientes a la tradición del derecho civil que cuentan con un sistema de disidencias (véanse los ejemplos ya dados anteriormente), así que no es conveniente realizar generalizaciones absolutas entre las tradiciones legales (las excepciones son demasiado frecuentes). La experiencia de estos países muestra que la modificación es posible, aun cuando varios de ellos provengan de una fuerte tradición de secretismo. Existen además casos de países como Alemania y España que, como ya se advirtió, han logrado introducir la disidencia judicial para materias constitucionales, lo que muestra que, al menos en dichos países, el secretismo no puede ser considerado como un dogma.

Por lo demás, es importante recordar que el desarrollo de las reglas que prohíben la publicidad de la disidencia es relativamente reciente, y no ha sido completamente congruente con todas las subtradiciones europeas. En efecto, existen antecedentes que demuestran que ciertos lugares que hoy son categorizados como pertenecientes a la tradición del derecho civil, han reconocido la existencia de un debate judicial de carácter público entre los jueces, o incluso la misma disidencia ${ }^{30}$.

30 Aquí hay algunos antecedentes: (1) bajo el temprano Derecho germánico y bajo los procedimientos romanos, muchas decisiones eran discutidas y entregadas en público; (2) algunos cantones suizos adoptaron una antigua tradición de deliberación pública que todavía existe. Nadelmann (1959) 415-416.; (3) aun cuando las disidencias no son permitidas en el Tribual Federal de Lausana, la deliberación judicial permanece abierta y es de acceso público. Häberle (2001) 181; (4) en Italia, antes de que el Derecho fuera unificado, "las opiniones disidentes eran entregadas en los reinos de Nápoles, los estados del Este y la Toscana". Nadelmann (1964) 269; (5) en Alemania hay algunos antiguos antecedentes que muestran que los votos particulares existieron algunos siglos atrás. Fernández (2009) 83-86; (6) “El 
Por otra parte, varias cuestiones están cambiando en la cuna del derecho civil europeo continental. El caso de Francia es de particular interés, ya que cuenta con una fuerte tradición de secretismo que se ha flexibilizado gracias a la presión de cortes internacionales ${ }^{31}$. Si bien estos cambios no han impulsado aun la publicación de los votos de minoría, los mismos muestran una creciente aceptación de un proceso de transparencia que el día de mañana podría vincularse perfectamente con nuestro tema. Como profundizaré más adelante, este proceso de agudización de la transparencia, unido al fenómeno de la constitucionalización e internacionalización del Derecho, presionan por la búsqueda de un nuevo estándar de legitimidad: uno más cercano al accountability ${ }^{32}$ y a la exposición sincera de las decisiones judiciales, y menos enfocado a la profesionalización de la judicatura y a las restricciones a que los jueces deben someterse (como ocurre con el literalismo y la ausencia de efectos expansivos por parte de las sentencias).

\section{(1.2) ACERCA DE CÓMO LA INTERNACIONALIZACIÓN Y LA CONSTITU- CIONALIZACIÓN DEL DERECHO ABREN NUEVOS ESPACIOS A LA REGLA DE TRANSPARENCIA JUDICIAL}

Más que contestar directamente la objeción de derecho comparado, este punto pone en perspectiva la evolución que los ordenamientos jurídicos experimentan de manera continua gracias a la constitucionalización y a la internacionalización del Derecho. Según explicaré, esta evolución resulta favorable a la adopción de reglas de transparencia en los países que se han resistido parcial o totalmente a utilizar las mismas. Argumentaré que, si dichos procesos se agudizan, entonces existirá más espacio para avanzar en la adopción progresiva de accountability, dentro de los cuales se encuentra la publicidad de las disidencias judiciales, los cuales, desde luego, deberán observar las particularidades propias de la tradición donde decidan insertarse.

derecho civil ha conocido tradiciones de ius civile, de ius gentium (...) o de disidencia (...)”. Glenn (2007) 345.

31 En efecto, la Corte Europea de Derechos Humanos ha establecido, entre otras cuestiones, que "(1) los litigantes individuales deben tener acceso a los documentos generados dentro de los debates internos de las cortes superiores francesas en la preparación de los argumentos orales, (2) que esos litigantes también deben tener la oportunidad de responder a dichos documentos, y (3) que ciertos magistrados clave (...) sean removidos de las deliberaciones internas de las cortes". Lasser, Michel (2009) Transforming Deliberations. En Huls, Nick, Adams, Maurice, y Вомноғf, Jacco (editores): The Legitimacy of Highest Courts' Rulings. Judicial Deliberation and Beyond. $1^{\text {a }}$ edición. New York: Cambridge University Press, pp. 50.

32 Como no existe en español un sinónimo exacto de la expresión inglesa accountability, prefiero utilizar la palabra en su idioma original. La misma denota una combinación entre rendición de cuentas y control, y se usa normalmente para calificar a ciertas instituciones que debieran operar bajo ciertos estándares de interés público. 
Como ya se señaló, algunos países de la tradición del derecho civil han tenido una evolución que está presente en sus cortes ${ }^{33}$, y no existe evidencia disponible acerca de que lo anterior haya tenido algún impacto negativo en la comunidad jurídica ${ }^{34}$. El desarrollo del constitucionalismo basado en el control constitucional, impulsará la existencia de un sistema de votos particulares, debido al gran impacto que las decisiones constitucionales pueden tener dentro del sistema político y social de un Estado ${ }^{35}$. El control constitucional implica resolver grandes preguntas jurídicomorales en las cuales la sociedad está dividida (protección del no nacido, obscenidad, la libertad de enseñanza, pena de muerte, etc.) y grandes preguntas políticas que interesan de manera conflictiva a actores relevantes (delimitación de competencias legislativas y regulatorias, desafuero de políticos, facultades de revisión judicial de actos emanados de órganos con legitimidad electoral, etc.). Todas estas preguntas, al ser resueltas, generan un alto impacto ${ }^{36}$. Lo anterior se intensifica cuando no existen estándares claros para que los jueces constitucionales trabajen. En efecto, las normas de textura abierta (dignidad, bien común) ${ }^{37}$, los conceptos jurídicos indeterminados (buenas costumbres, moral) y el tratamiento de los derechos fundamentales como principios jurídicos (igualdad e isonomía, libertad y subsidiariedad), hacen crecer la discrecionalidad del juez constitucional al aumentar la cantidad de respuestas posibles a que este puede llegar ${ }^{38}$.

Mientras más Derecho Constitucional exista, más se les pedirá a los jueces constitucionales que resuelvan este tipo de preguntas. Y mientras más preguntas como estas existan en manos de dichos jueces, mayores disidencias naturales se producirán al interior de las cortes. Y no solo en cantidad, sino que también en intensidad. Mientras más secretismo exista, más frustraciones existirán dentro de los partidarios de las numerosas e intensas preferencias alternativas. Si a lo anterior se suma que al contestar dichas preguntas con fuerza constitucional los jueces reducen el ámbito democrático de discusión natural en órganos electos (Congreso), entonces la presión porque las visiones disidentes tengan un espacio en el debate

Véase Fernández (2009).

En el caso de Alemania, véase Fernández (2009) 118-119.

Una argumentación similar ha sido brevemente desarrollada por Peter Häberle, para quien existe una conexión entre los votos particulares y la teoría constitucional, ya que dichos votos son la "expresión de la publicidad y del carácter abierto de la Constitución, la franqueza de sus intérpretes y el pluralismo de la Constitución (...)”. HäBerle (2001) 180.

36 Por lo mismo, "[e]l constitucionalismo en sí mismo solo puede crecer cuando las cortes están autorizadas a operar abiertamente, donde cada juez puede anunciar y justificar su voto". Nadelmann (1964) 276.

37 Véase Hart, H.L.A. (1961 y 1994) The Concept of Law. 1a y 2a edición. New York: Oxford University Press, pp. 124-136.

38 FERNÁNDEZ (2009) 83, coincide en que las sentencias constitucionales son más propensas a tener disidencias, debido al alto nivel de discreción con que cuentan los jueces en la interpretación de la Constitución. 
público crecerá. Por lo anterior, el constitucionalismo (fuerte) favorece la manifestación de los votos particulares ${ }^{39}$, y los ordenamientos jurídicos sin un constitucionalismo (fuerte) dependen menos de la publicación de los mismos, como ocurre con el caso francés.

El argumento del constitucionalismo no solo se extiende a la existencia de cortes estrictamente constitucionales (Consejo Constitucional francés ${ }^{40}$, etc.), sino que también puede ser utilizado en todos aquellos tribunales dotados de la capacidad de interpretar la Constitución, ya sea (a) en el ejercicio del control de constitucionalidad de diversas fuentes jurídicas (como el control de los actos administrativos que realiza el Consejo de Estado francés o el control vía nulidad de Derecho Público o recurso de protección en Chile, etc.); (b) ya sea en acciones de amparo de derechos fundamentales; o (c) en la interpretación de fuentes infraconstitucionales utilizando la Constitución como canon de interpretación (interpretación conforme, sentencias interpretativas o manipulativas, etc.). Sin perjuicio de lo anterior, es cierto que el argumento del constitucionalismo cobra una especial fuerza en el caso las cortes constitucionales y se debilita cuando otras cortes resuelven casos que se alejan del constitucionalismo, donde existen estándares jurídicos más predecibles de solución y la discusión se centra más en los hechos y menos en el Derecho (en Chile, la acción derivada de la ley de arrendamiento de predios urbanos, la tercería de prelación, etc. $)^{41}$.

El crecimiento del constitucionalismo, por lo tanto, resulta fundamental en el análisis del modelo de disidencias, especialmente cuando se considera que la constitucionalización del Derecho está cada vez más fortalecida en los países del derecho continental europeo ${ }^{42}$ (y también en Latinoamérica), a través del cual los derechos fundamentales y las Constituciones están ganando más importancia en la interpretación de normas infraconstitucionales.

39 Un ejemplo de lo anterior (un caso de estudio) que se presentó en Alemania, donde los casos cercanos a la política estimulan mayores niveles de disidencia, está documentado por Amram (1958).

40 El caso francés resulta de especial interés, ya que el control al legislador por el respeto de la Constitución, se encuentra basado en el contexto de la regla del secretismo. Sin embargo, el Consejo Constitucional se está transformando en "una institución que atrae una revisión sustancial de las leyes sobre la base de los derechos fundamentales". Lasser (2009) 50.

41 Por lo anterior, en los países del derecho civil que no cuentan con tribunales constitucionales (como Holanda, por ejemplo), el argumento del constitucionalismo no debiera operar con la misma importancia.

42 Véase el trabajo del profesor francés Louis Favoreu, para quien la historia del Derecho está cambiando, poniendo a la Constitución como "centro de gravedad" del sistema jurídico. Antes estaban las leyes, y ahora es la Constitución Favoreu, Louis Joseph (2001). "La Constitucionalización del Derecho". Revista de Derecho (Valdivia), vol. 12, no.1, pp. 31-43. Disponible en: http://mingaonline.uach.cl/pdf/revider/v12n1/art03.pdf. Para una visión crítica en la doctrina nacional, véase CorReA, Rodrigo (2009): "Vulgarización por constitucionalización". Facultad de Derecho Universidad de Chile: Democracia y Derechos Fundamentales desde la Filosofía Política. Santiago: Editorial Jurídica de Chile, pp. 35-54. 
El proceso de constitucionalización se complementa, como ya se señaló, con la internacionalización del Derecho. En efecto, gran parte de los países del derecho civil continental europeo (entre los que tienen reglas de secretismo) han aceptado la jurisdicción de ciertas cortes internacionales, las que suelen operar de manera diferentes a las judicaturas domésticas, siendo más cercanas a la regla de transparencia. Un ejemplo es la Corte Europea de Derechos Humanos, la que cuenta con un modelo de disidencias ${ }^{43}$. Otro ejemplo es el Tribunal Internacional de Justicia. Un ejemplo contrario que no cuenta con un sistema de voto particular es la Corte Europea de Justicia, la que sin embargo trabaja con ciertas reglas de transparencia que, si bien no son sinónimo de publicidad de disidencias, permiten que los desacuerdos internos sean dados a conocer de manera indirecta, lo que se opone a las prácticas de secretismo que utilizan algunas cortes como las francesas ${ }^{44}$. Las decisiones de estas cortes son fuente válida y se incorporan a los ordenamientos jurídicos nacionales ${ }^{45}$, coexistiendo con sentencias basadas en modelos de secretismo judicial. Como estas cortes internacionales permiten la publicidad de los desacuerdos (sea o no a través del modelo de disidencias judiciales), los países que se encuentran bajo su jurisdicción también han admitido la existencia de los mismos. Sin embargo, no existe evidencia de que lo anterior haya producido un impacto negativo, al menos por causa de la mayor transparencia.

Es importante considerar que aquellos países que no cuentan con cortes constitucionales con un sistema de control constitucional (como Holanda), han adoptado alguna forma de control por la vía del Derecho Internacional, donde la jurisprudencia de estas cortes se ha vuelto especialmente relevante ${ }^{46}$.

En suma, la tradición del derecho civil no es contradictoria con la utilización de disidencia, aunque ello no significa que la misma pueda operar sin resistencia. Sin embargo, un estudio acerca de los beneficios de la implementación de un modelo de votos particulares exige analizar los sistemas legales domésticos caso a caso, ya que dentro de ellos es posible encontrar una diversidad importante tanto en las reglas vigentes, como en

43 Véanse las sentencias de esta Corte en http://www.echr.coe.int/echr/Homepage_En

44 A modo de ejemplo, como documenta Lasser, la práctica de la Corte Europea de Justicia consiste en que la publicación simultánea la decisión final junto con la opinión del Abogado General (Advocate General). Lo anterior "significa que los magistrats de la propia Corte claramente ponen múltiples perspectivas en la tabla para cada caso, llevando a una ventilación permanente de explícito y serio desacuerdo". LASSER (2004) 203.

45 Schoenberger, Allen (2009). "Change in the European Civil Law Systems: infiltration of the Anglo-American Case Law system of Precedent into the Civil Law System". Loyola Law Review, vol. 55, pp. 5-21.

46 Véase un argumento relacionado, que justifica la presencia de votos particulares dentro de los Tribunales, sugiriendo que ellos son la expresión de la soberanía y que son actores fundamentalmente políticos, en Medina Rubio (2000) 306-307. 
su historia y cultura jurídica. Así, por ejemplo, un análisis de la regla de transparencia para aplicarla en Italia, será muy diferente al que se utilizaría en China.

No obstante lo anterior, resulta útil para dicho análisis particular el comenzar por un marco teórico donde las ventajas y defectos del modelo de disidencias sean expuestos y ponderados de una manera más general, sin considerar una tradición jurídica específica, utilizando para ello la premisa de la existencia de una democracia constitucional. Por lo anterior, los siguientes capítulos de este trabajo solo podrán ser aplicables en aquellos países donde se quiera avanzar en mayores niveles democráticos, razón por la cual el mismo tendrá mayor asidero cuando se analicen países como Italia, y menos cuando se estudien países como China.

\section{2) ¿POR QUÉ ES CONVENIENTE PROHIBIR LA PUBLICACIÓN DE LAS DISIDENCIAS? (¿Y POR QUÉ ESTAS RAZONES NO SON COMPLETA- MENTE CONVINCENTES?)}

Las razones que se han esgrimido para promover la práctica del secretismo judicial pueden ser resumida en cinco argumentos principales: (2.1) la sentencia unánime entrega mayor (ilusión de) certeza acerca del contenido del Derecho; (2.2) ella muestra unidad entre los jueces de la Corte, fortaleciendo la legitimidad de sus decisiones (y favoreciendo su independencia respecto de otras instituciones); (2.3) la unanimidad fortalece la calidad de la sentencia final; (2.4) disminuye la carga de trabajo de los jueces en particulares, permitiéndoles lidiar mejor con las normalmente colapsadas tablas judiciales; y (2.5) evita crear animadversión entre los jueces de una misma corte.

\section{(2.1) CERTEZA ACERCA DEL CONTENIDO DEL DERECHO}

Este argumento consiste en que "(...) el Derecho es cierto y debe aparecer como tal, y (...) la certeza se reduciría al observar disidencias y al publicar opiniones judiciales separadas" 47 . Para los que sostienen este argumento, el propósito de las disidencias es eliminar la ilusión de unidad y solidaridad ${ }^{48} 49$.

\footnotetext{
47 Merryman (2007) 122.

48 Scalia (1994) 35. Un argumento similar ha sido hecho (pero no compartido) por el juez Brennan: “(...) los críticos de la disidencia abogan por la primacía de la unidad sobre sus miembros y argumentan que la Corte es más legítima, más fiel a su papel previsto, cuando habla con una sola voz". Brennan (1986) 432.

49 Robert Bennett ha argumentado que la disidencia puede perjudicar el carácter predecible del Derecho Constitucional, haciendo que el precedente sea más débil. BennetT (1991) 260. Es cierto que un compromiso fuerte con el precedente (lo que él llama institutional sense) haría que los disidentes de un caso puedan cambiar sus votos en casos similares futu-
} 
Existen varias maneras de relativizar la defensa de este argumento. Así, por ejemplo, el juez Scalia ha dicho que (a) la autoridad de la Corte descansa en la prevalencia del voto de mayoría y que (b) aun cuando la población se pueda ver más inclinada a aceptar una decisión basada en la unanimidad, ello no sería muy diferente a cuando el Congreso toma una decisión ${ }^{50}$. La analogía que Scalia realiza entre la Suprema Corte y el Congreso es, sin embargo, problemática. El rol de la Corte consistente en decir fielmente lo que el Derecho es ${ }^{51}$, es muy diferente al que tiene el Congreso como creador del Derecho legislado. Si bien Scalia podría contraargumentar que en la práctica las cortes también crean Derecho, y que el Congreso también interpreta el Derecho (especialmente la Constitución), existe, a lo menos una diferencia de grado en el rol de ambos poderes (uno es más creador y el otro es más intérprete), que se vincula con el tipo de autoridad que ambas tienen. En efecto, mientras el creador basa su autoridad en elecciones democráticas, el intérprete basa su autoridad en el contenido de sus decisiones, cuyo garante es la independencia del autor de las mismas (los jueces). No son, por consiguiente, instituciones equivalentes en este sentido.

Otra respuesta es posible frente al argumento de la certeza. Dicha respuesta debe dimensionar con una perspectiva correcta el verdadero alcance que tiene la unanimidad lograda a través del sistema de secretismo. En efecto, con este sistema la unanimidad es solo teórica, ya que en la realidad ella significa una suposición artificial que el modelo judicial inventa. La unanimidad forzada equivale a una unanimidad ficción, ya que ella no significa que los jueces de un tribunal colegiado coincidan con una misma respuesta jurídica al problema concreto que se plantea, sino que solo significa que las opiniones disidentes son ocultadas a las partes y a la comunidad. El juego de mayorías y minorías existe, solo que a la mayoría se le llama sentencia y la opinión de la minoría no es conocida públicamente. La mayoría, entonces, existe y se impone. Considerando esto, cualquier certeza, unidad o solidaridad es, en los hechos, ilusoria ${ }^{52}$.

¿Es capaz, esa unidad ilusoria, de entregar certeza? Veamos. La certeza implica el conocimiento acerca de lo que el Derecho es, en particular,

ros, pero eso no es un argumento en contra de la disidencia, sino que contra del abuso de la disidencia, como explicaré más adelante.

50 SCALIa (1994) 35.

51 Este es el rol de la Corte Suprema según la fundacional sentencia Marbury v. Madison, 5 U.S. (1 Cranch) 137 (1803). Una visión moderna del rol de las cortes indica que el rol de ellas es llegar a una respuesta jurídica correcta. Así, por ejemplo, Dworkin ha dicho que ellas deben entregar una única y mejor "respuesta correcta". Dworkin, Ronald (1985) A Matter of Principle. $1^{\text {a }}$ edición. New York: Oxford University Press, pp. 119-145. La legitimidad de la Corte, entonces, estaría relacionada con el contenido de sus decisiones.

52 En las palabras del juez Stone, "las opiniones disidentes tienden a romper la apreciada ilusión de certeza en el Derecho y de la infalibilidad de los jueces". Stone (1943) 78. 
de lo que los jueces dicen que el Derecho es. Así, la certeza exige consistencia en la interpretación judicial de la norma jurídica y, desde luego, ella dependerá de la capacidad que tenga la comunidad jurídica para anticipar el comportamiento de los jueces en el futuro. Si la interpretación judicial cambia en el futuro, la certeza dependerá, entonces, de la capacidad de la comunidad para predecir el cambio (o la posibilidad de que este cambio, en los hechos, ocurra). Como la información que el modelo de secretismo le entrega a la comunidad jurídica es incompleta, esta no podrá predecir las futuras sentencias, especialmente frente a posibles cambios en la composición del tribunal. Con el secretismo, no se sabe exactamente cuán fuerte es la mayoría dentro de un tribunal, o se cree erróneamente que una doctrina es unánime, en circunstancias que no necesariamente lo es. Así, un pequeño cambio en la integración del mismo podría hacer cambiar una doctrina jurídica que la comunidad no pudo anticipar.

Por consiguiente, el secretismo no entrega certeza, sino que una ilusión de certeza. Podría pensarse por algunos que esa ilusión tiene algún valor, ya que a las instituciones relacionadas (el Ejecutivo, el Congreso, las otras cortes, etc.) y a la comunidad jurídica (profesores, abogados, etc.) probablemente les interesa la manera en que la decisión judicial que les afecta ha sido creada. Podría también pensarse que, al ocultar la composición de la verdadera mayoría dentro de la corte, la regla de secreto podría conducir a una ilusión de unidad que, eventualmente, contribuiría a fortalecer la independencia de la corte frente a los actores interesados ${ }^{53}$. Después de todo, sigue el argumento, el Estado de Derecho solo admite una respuesta final, por lo que las voces disidentes no son, en estricto sentido, voces propias de un sistema de Derecho coherente y armónico ${ }^{54}$.

53 En palabras de Michel Lasser, referidas al sistema francés: "Al insistir con el carácter impersonal de las sentencias colegiadas, el sistema judicial francés perjudica -y tal vez efectivamente niega- el individualismo del juez, simbolizado primero con su firma y segundo con su capacidad de ser una voz en sus preocupaciones individuales, por la vía de la publicación de sus opiniones concurrentes y disidentes". LASSER (2009) 36.

54 La cultura jurídica del derecho civil suele asumir una teoría general del ordenamiento jurídico donde todas las normas son coherentes y armónicas entre sí y no existe contradicción normativa posible (o ella debe ser superada). Esto se basa, en gran medida, en la tesis de Hans Kelsen sobre la estructura del orden jurídico, donde se señala que "[u]na ciencia normativa no puede admitir contradicción entre dos normas que pertenecen al mismo sistema. Ahora bien, el derecho mismo resuelve el conflicto posible entre dos normas válidas situadas en estratos diferentes, de tal manera que ninguna contradicción lógica afecta la unidad del orden jurídico en su estructura jerárquica”. Kelsen, Hans (1994) Teoría pura del derecho. Introducción a la ciencia del derecho. Traducción de: Moisés Nilve. 28 a edición. Buenos Aires: Editorial Universitaria de Buenos Aires, pp. 161. En Chile, véanse algunos ejemplos acerca de la creencia en un sistema jurídico basado en la unidad y coherencia de sus normas en, Rodríguez Grez, Pablo (1999) El derecho como creación colectiva. Santiago: Editorial Universidad del Desarrollo Ediciones Jurídicas, pp. 139-147, quien expone la idea de coherencia como presupuesto del Estado de Derecho; Squella Narducci, Agustín (2000) 
Lo anterior representa un deseo acerca del Estado de Derecho que contrasta con la realidad práctica: los jueces frecuentemente discrepan, no importando en qué sistema ellos trabajen ${ }^{55}$. ¿Cómo, entonces, enfrentar esta realidad? ¿Debería ocultarse la discrepancia? ¿O debería darse a conocer? La primera alternativa coincide con una visión idealista del Derecho, que observa a los jueces como integrantes de un solo cuerpo que no admite separación: el tribunal. La segunda alternativa es más pragmática, y observa el Derecho como una realidad práctica, donde se personaliza la labor de los jueces entendiendo que ellos son actores en sí mismos ${ }^{56}$. ¿Cuál de estas dos concepciones entrega mayores garantías de certeza jurídica? ¿La idealista o la pragmática?

El valor de la ilusión de certeza necesita ser ponderado con la incerteza que el secretismo genera si se acepta el hecho de que los jueces discrepan. Solo así los actores interesados podrán saber cuán fuerte es una sentencia. Por fuerte me refiero a aquella sentencia que es apoyada por un amplio número de jueces y que, por lo tanto, la doctrina jurídica en ella utilizada debiera tener mayor resistencia frente a los posibles cambios en la integración del tribunal. Una sentencia débil, por el contrario, es aquella cuya doctrina está más sujeta a posibles vaivenes debido a cambios de integración ${ }^{57}$. Si se publican las opiniones disidentes, entonces la comunidad (jurídica) puede evaluar la fuerza que una doctrina jurídica tiene dentro de una corte. Así, por ejemplo, en el Tribunal Constitucional chileno, probablemente no tenga la misma fuerza la posición de una decisión alcanzada con seis votos, que una alcanzada con el apoyo de diez ministros. La primera será probablemente más fácil de cambiar en el futuro, sobre todo cuando se considera que, en el ejemplo, los ministros del Tribunal Constitucional solo duran nueve ańos en sus funciones y se renuevan por parcialidades cada tres. En suma, mientras más controvertida sea una decisión, más probable será que cambie la doctrina que ella invoca.

Introducción al derecho. $1^{\text {a }}$ edición. Santiago: Editorial Jurídica de Chile, pp. 337-344, quien cita a Hans Kelsen y a Norberto Bobbio; y a Williams Benavente, Jaime (1999) Lecciones de introducción al derecho. $3^{\text {a }}$ edición. Santiago: Editorial Ediciones Fundación de Ciencias Humanas, pp. 251 y 252, quien asume que la armonía es una característica del ordenamiento jurídico.

55 "Las disidencias a veces revelan amplias diferencias en las visiones filosóficas, o expone diferentes gustos o idiosincrasias entre los jueces; que hacen estallar el mito de que las preguntas jurídicas solo admiten una sola respuesta correcta". Friedmann, Lawrence, et alii (1981). "State Supreme Courts: A Century of Style and Citation". Stanford Law Review, vol. 33, pp. 785.

56 Por esta razón, Michel Lasser ha dicho que el sistema judicial francés "representa una afrenta a las lecciones del realismo legal norteamericano, que por más de cincuenta ańos ha constituido el fundamento intelectual ortodoxo del sistema jurídico de los EE.UU.” Lasser (2009) 36.

57 Por supuesto, como recuerda Douglas, un argumento así no podría ser aplicable bajo sistemas no democráticos, donde probablemente la unidad en el Derecho es lograda gracias a un Ejecutivo fuerte que influye (o presiona) a los jueces. Douglas (1948) 105. 
El saber cómo las mayorías están cambiando al interior de un tribunal, requiere que esté disponible la información acerca de cómo votan los jueces, ya que de lo contrario no podríamos conocer los acuerdos y discrepancias internas. Tener esa información fortalece la certeza acerca de cuán fuerte es una determinada interpretación jurídica y, en consecuencia, acerca de qué es lo que el Derecho dicta o dictará en el futuro ${ }^{58}$. Por supuesto, es imposible garantizar una completa certeza jurídica ${ }^{59}$, pero una completa certeza tampoco sería conveniente, ya que el Derecho es también el resultado de un proceso político flexible y democrático. De esta manera, el juez Douglas ha argumentado que cuando los jueces expresan posiciones contrapuestas, es probable que ello se deba a que también existe una controversia en la sociedad ${ }^{60}$. En Chile hay numerosos ejemplos de ello a nivel de nuestro Tribunal Constitucional, como ocurre con el caso píldora del día después ${ }^{61}$, ISAPRES ${ }^{62}$, sodomía ${ }^{63}$, televisión

58 Un argumento similar puede verse en FleTCher (2009) 298.

59 Por eso las palabras de Joe W. Sanders son útiles: El "[d]erecho mismo es incierto", así que "la acusación de incerteza debe ser rechazada". SANDERS (1963) 677. Sin embargo, también creo que un cierto mínimo de certeza es necesario dentro de un Estado de Derecho, ya que de lo contrario viviríamos en un mundo sin reglas estables, un mundo arbitrario. Como las reglas son importantes, el Derecho debe proporcionar algún grado de certeza, y las disidencias colaboran con ello.

60 Douglas (1949) 106.

61 Tribunal Constitucional. 18 de abril de 2008. Rol 740-2008. Requerimiento de inconstitucionalidad en contra de algunas disposiciones de las "Normas Nacionales sobre Regulación de la Fertilidad" aprobado por el Decreto Supremo $N^{\circ} 48$, del 2007, del Ministerio de Salud. Disponible en: http://www.tribunalconstitucional.cl/index.php/sentencias/view/914 [fecha vista 14 de julio de 2011].

62 Tribunal Constitucional. 26 de junio de 2008. Rol N 976-2008. Requerimiento de inaplicabilidad deducido por Silvia Peña Wasaff respecto del artículo 38 ter de la Ley No 18.933, conocida como Ley de Isapres, en recurso de protección contra Isapre ING Salud S.A., Rol de Ingreso No 4972-2007, de la Corte de Apelaciones de Santiago. Disponible en: http://www.tribunalconstitucional.cl/index.php/sentencias/view/957[fecha vista 14 de julio de 2011]. Hay varios casos más que siguen la línea de la sentencia citada. El último de ellos, que declaró la inconstitucionalidad de la norma impugnada con efectos generales es: Tribunal Constitucional. 6 de agosto de 2010. Rol $N^{\circ} 1710$. Proceso iniciado de oficio para decidir sobre la constitucionalidad del artículo 38 ter de la Ley de Isapres y cuya sentencia se publicó en el Diario Oficial el 9 de agosto de 2010. Disponible en: http:// www.tribunalconstitucional.cl/index.php/sentencias/view/1479. [fecha vista 14 de julio de 2011].

63 Tribunal Constitucional. 4 de enero de 2011. Rol N 1683-2011. Acción de inaplicabilidad por inconstitucionalidad de Jorge Washington Sepúlveda Álvarez respecto del artículo 365 del Código Penal, en la causa RIT N 1287-2008, RUC Nº 0800242317-1, seguida ante el Juzgado de Garantía de Cañete. Disponible en: http://www.tribunalconstitucional.cl/index. php/sentencias/view/1715. [fecha vista 14 de julio de 2011] 
digital $^{64}$, cibercafés $^{65}$ y en el caso postnatal ${ }^{66}$. Expresar un cierto nivel de diversidad judicial es también representar mejor las posiciones que existen dentro de nuestra sociedad. Este argumento, por supuesto, es irrelevante si se asume que los jueces no tienen nada que ver con la democracia. Sin embargo, si se cree que los jueces deben operar con estándares democráticos, el mismo cobra fuerza. No puede desconocerse, sin embargo, que las posiciones en este sentido están probablemente divididas, lo que debilita el argumento.

Por otra parte, una crítica relacionada al modelo de disidencias señala que ellas ocasionan un problema de cumplimiento en el valor que la doctrina jurídica que una sentencia dividida invoca ${ }^{67}$. Esta crítica argumenta que una sentencia dividida en las cortes superiores, tiende a ser menos seguida por los tribunales inferiores que una que goza de unanimidad. De esta manera, el valor del precedente (en los sistemas de derecho anglosajón) y el valor moral o el prestigio de una sentencia (en los sistemas de derecho civil) tienden a ser más fuertes cuando las cortes superiores se muestran unidas. Este argumento, de ser cierto, probablemente tendrá más cabida en aquellos sistemas donde la interpretación jurídica depende mayormente del stare decisis. En cualquier caso, debe considerarse que este es un argumento teórico que tiene una pretensión empírica. Como tal, por consiguiente, debe evaluarse de forma empírica: ¿son menos respetadas judicialmente aquellas sentencias dictadas de manera no unánime? La escasa evidencia sugiere que esta tesis no es real. En efecto, un estudio orientado a analizar la obediencia de las cortes inferiores en EE.UU. respecto de sentencias de la Suprema Corte, dictadas entre 1961 y 1963, indica que el grado de apoyo o no apoyo de sentencias de la

64 Tribunal Constitucional. 12 de mayo de 2011. Rol No 1849-2011. Requerimiento de inconstitucionalidad de 36 Diputados respecto del Decreto Supremo No 264, del Ministerio de Transportes y Telecomunicaciones, publicado en el Diario Oficial de 6 de octubre de 2010, que "Fija normas complementarias al Decreto No 136 de 14 de septiembre de 2009". Disponible en: http://www.tribunalconstitucional.cl/index.php/sentencias/download/ pdf/1927. [fecha vista 21 de julio de 2011].

65 Tribunal Constitucional. 12 de julio de 2011. Rol No 1894-2011. Control de constitucionalidad del proyecto de ley que sanciona el acoso sexual de menores, la pornografía infantil y la posesión de material pornográfico infantil. (Boletín No 5837-07). Disponible en: http://www.tribunalconstitucional.cl/index.php/sentencias/download/pdf/2011 [fecha vista 21 de julio de 2011].

66 Tribunal Constitucional. 20 de julio de 2011. Rol No 2025-2011. Requerimiento del Presidente de la República respecto de la inconstitucionalidad de "la actuación del Senado y la consecuente modificación introducida por este al artículo 197 bis del Código del Trabajo" contenido en el proyecto de ley que crea el permiso postnatal parental y modifica el Código del Trabajo (Boletín No 7526-13). Disponible en: http://www.tribunalconstitucional.cl/ index.php/sentencias/download/pdf/2047 [fecha vista 21 de julio de 2011].

67 Véanse algunos académicos que han sostenido esta posición, aún antes de evaluarla empíricamente, en Johnson, Charles A. (1979). "Lower Court Reactions to Supreme Court Decisions: A Quantitative Examination”. American Journal of Political Science, Vol. 23, No 4: pp. 792-793. 
Suprema Corte en casos particulares, tiene poca o ninguna influencia en el tratamiento de casos por parte de cortes inferiores ${ }^{68}$.

Esta evidencia no es suficiente para descartar la crítica. Sin embargo, a ella se suma el hecho de que (de aceptar que la crítica sea cierta) en los países que siguen el derecho civil las sentencias judiciales no son una fuente del Derecho tan relevante como en los países del derecho anglosajón, razón por la cual las opiniones minoritarias no pueden hacer tanto daño a la influencia de los fallos en la determinación del Derecho.

Para resumir, la regla de secreto crea una ilusión de certeza que debe ser ponderada con la necesidad de transparentar el sistema judicial. La ilusión de certeza tiene ciertas debilidades que debemos considerar, como (a) el hecho de que es artificial; y (b) ella no ayuda a predecir el futuro comportamiento de los tribunales. El sistema de transparencia tiene la desventaja de no mostrar unidad dentro de la corte (y, en definitiva, del ordenamiento jurídico), pero (a) colabora de manera más eficaz a entender la realidad dentro de las cortes; y (b) ayuda mejor a predecir las futuras posiciones de las cortes colegiadas atendidos los cambios en su integración.

\section{(2.2) LA UNANIMIDAD FAVORECE LA LEGITIMIDAD DE LA CORTE}

Según este argumento, las disidencias debilitan la decisión mayoritaria. Para quienes sostienen este punto, el Derecho no debiera consistir en contar un mero número de votos ${ }^{69}$. La disidencia no es deseable para la unidad del Derecho y, por lo tanto, ella tendría un impacto negativo en la autoridad de las cortes ${ }^{70}$. Una opinión unánime favorece mejor la aceptación de la decisión judicial por parte de la comunidad y de los actores legales relacionados ${ }^{71}$.

68 Johnson (1979) 802. Después de eso, Johnson agrega que "[a] unque en algunas instancias los niveles de apoyo están ligeramente relacionados con evasivas y discordantes respuestas, el monto de varianza en estas reacciones de la corte inferior es muy bajo. En realidad, no más del 5 por ciento de la varianza ha contado para alguna medición del apoyo de la Suprema Corte en alguna sentencia. No se está diciendo que las decisiones de la Suprema Corte sean ignoradas, pero en cambio que su tratamiento, cuando ha sido citado, ha tenido poco que ver con objetivos políticos de la Corte y con el apoyo de esas políticas sobre la Corte". JoHnson (1979) 802-803.

69 Robert Bennett, por ejemplo, ha dicho que las "[d]isidencias muestran la falibilidad en el Derecho, y en consecuencia estimulan las dudas acerca de su legitimidad". BenNetT (1991) 257.

70 Rousseau (2002) 50.

71 Así, por ejemplo, los jueces Felix Frankfurter y Earl Warren intentaron exitosamente realizar una decisión unánime en Brown v. Board of Education. 347 U.S. 483 (1954). Esta sentencia, histórica para la igualdad, fue favorecida con una relativa mayor aceptación debido a su carácter unánime, el que ayudó en un contexto de mucho conflicto. Sin embargo, no puede desconocerse que la aceptación de este fallo estuvo lejos de ser pacífica. Sobre esto, véase Klarman, Michael J. (2007) Brown V. Board of Education and the Civil Rights Movement. 
Para que este argumento funcione, deben cumplirse con los siguientes supuestos: (a) que el Derecho sea considerado como una unidad independiente de la manera en que las decisiones se toman dentro de una Corte; (b) que los diferentes sistemas jurídicos tengan un mismo acercamiento al concepto de legitimidad del tribunal; (c) que la legitimidad basada en la aceptación sea uno de los objetivos válidos de los tribunales; y (d) que existen estudios empíricos que demuestran una conexión entre unanimidad y aceptación.

El problema es que los supuestos anteriores no son necesariamente reales, razón por la cual esta desventaja del sistema de disidencias se debilita. En efecto, (a) el Derecho no es independiente de la votación que se produce para tomar una decisión dentro de una Corte, ya que justamente la interpretación jurídica depende de la solución que mayoría ofrezca ${ }^{72}$. En este punto, volvemos a la dicotomía detectada anteriormente respecto de las teorías idealistas del Derecho y de las visiones pragmáticas del mismo.

Para examinar el segundo punto (b), relativo al problema del acercamiento comparado del concepto de legitimidad judicial, útil resulta el trabajo de Michel Lasser, quien ha mostrado que los sistemas norteamericano y francés tienen dos maneras diferentes para entregar legitimidad sus cortes $^{73}$. Ambos conceptos de legitimidad judicial (el norteamericano y el francés) son válidos, pero no son necesariamente compatibles. En general, explica Lasser, la legitimidad judicial dependerá de la coherencia que experimente el actor legal con la narrativa que el propio sistema persigue (master narrative, en palabras del autor) ${ }^{74}$. En EE.UU., la legitimidad judicial se logra a través de la transparencia y el accountability ${ }^{75}$, mientras que en Francia se logra a través de factores como la profesionalización de la judicatura y el rol restringido de los jueces dentro del sistema políti$\mathrm{Co}^{76}$. La regla de secretismo parece ser, en este sentido, parte de la narrati$v a$ francesa.

Elegir un concepto de legitimidad u otro de manera absoluta puede resultar arbitrario, ya que implicaría exigirle a un ordenamiento jurídico dar cumplimiento a estándares que el mismo no se ha propuesto. Sin embargo, por lo explicado anteriormente, la penetración del derecho constitucional e internacional como fuentes directas del Derecho, presionan

The abridged edition of "From Jim Crow to Civil Rights: The Supreme Court and The Struggle for Racial Equality”. 2a edición. New York: Oxford University Press, pp. 175-184.

72 Véase, por ejemplo, la visión de Pritchett (1941) 890.

73 Esta diferencia explica por qué en el "nivel de la teoría política el formato judicial francés representa una afrenta en contra de la ética norteamericana de la participación democrática”. LASSER (2009) 36.

LASSER (2009) 38.

LASSER (2009) 38-39.

LASSER (2009) 42-43. 
por un modelo de legitimidad más parecido al norteamericano. El mismo sistema francés está modificando su estructura gracias a la influencia de cortes internacionales y a la utilización de los derechos fundamentales como parte del derecho judicial aplicado, tal y como ya expliqué y el mismo Lasser documenta ${ }^{77}$.

El tercer supuesto (c), indica que la decisión de la corte se basa en la aceptación de la misma por parte de la comunidad (o, al menos, por parte de las elites) en ciertos casos excepcionales de gran impacto como pildora del día después ${ }^{78}$. No existe consenso en la doctrina respecto a si la legitimidad es un objetivo válido por parte de los jueces. En efecto, y como ya se indicó, la mayoría de los jueces del derecho civil trabajan utilizando un razonamiento deductivo que intenta aplicar la ley. Una consecuencia de esta técnica, combinada con la profesionalización de una judicatura jerárquica, implicaría que el rol del juez es dictar sentencias sin considerar las consecuencias de la misma ${ }^{79}$. Después de todo (diría defensor de esta manera de ver el Derecho) una mala ley no es responsabilidad de un juez, ya que este último no es un creador del Derecho ${ }^{80}$. Si se cree (en serio) que esta concepción es la correcta, entonces la legitimidad (y aceptación) de las decisiones judiciales no sería un aspecto relevante a la hora de discutir si queremos o no tener un sistema que permita la publicidad de las disidencias, ya que no sería necesario utilizar la unanimidad para favorecer la aceptación de las sentencias. Al no ser un objetivo en la labor de los jueces, con el formalismo no se le podría exigir a los mismos que consideren este problema.

Sin perjuicio de que la visión anterior probablemente es la predominante dentro de la cultura jurídica nacional, y atendido que mi trabajo utiliza un supuesto basado en la democracia y en el rol de jueces constitucionales, aceptaré que el supuesto de la legitimidad es cierto. Correspon-

LASSER (2009) 50-52.

Tribunal Constitucional. Rol N ${ }^{\circ} 740-2008$.

Esta visión contrasta con otras perspectivas acerca de la legitimidad de las cortes. Si creemos, como Jeremy Waldron cree, que las cortes no deben resolver aquellos casos donde la propia corte refleja los mismos desacuerdos que se observan dentro de la sociedad (esta es una materia del Congreso, que debe resolverse por regla de mayoría, según Waldron), entonces el problema de la legitimidad no sería acerca de la disidencia, sino que acerca del poder de las cortes. Véase WALDron, Jeremy (2001) Law and Disagreement. $1^{\mathrm{a}}$ edición. New York: Oxford University Press, pp. 344. Esta discusión sobre la legitimidad del poder de las cortes no la trato en este trabajo, aunque es útil recordar que la misma tiene más cabida si se acepta la visión de que los jueces crean Derecho. En Chile, véase el debate entre Atria, Fernando (1993). "Tribunal Constitucional y Objeción Democrática". Revista Chilena de Derecho, vol. 20, No 2-3, pp. 367-378. y Atria, Fernando (2000) Revisión Judicial: el Síndrome de la Victima Insatisfecha. Estudios Públicos, N 79. Disponible en: http://www.cepchile.cl/ dms/lang_1/doc_1081.html y Zapata Larraín, Patricio (2008) Justicia Constitucional. Teoría y práctica en el derecho chileno y comparado. Santiago: Editorial Jurídica, pp. 623.

80 Merryman (2007) 17 y 23-25; GlenN (2007) 136. Véase un acercamiento alternativo y práctico (que comparto) en Merryman (2007) 83. 
derá, entonces, verificar si es cierta la consecuencia que se supone seguir de la crítica basada en la legitimidad y aceptación.

En primer lugar, para que dicha crítica opere se requiere de mayor evidencia acerca de la reacción de la comunidad frente a decisiones unánimes. Si la comunidad acepta más fácilmente las decisiones unánimes (solo por ser tales), ello se debe probablemente a que la corte representa relativamente los consensos que ya existen en la sociedad, y no necesariamente a la unanimidad. En otras palabras, nadie pensaría que la legitimidad de una corte (y de sus sentencias) se vería perjudicada por fallar un caso de manera contraria a la manera que la sociedad en general comparte, solo por existir un voto disidente. En este sentido, la aceptación parece más asociada al resultado de la sentencia (su parte resolutoria), y un posible problema de legitimidad dependerá en la capacidad del disidente de influir en el debate público. Si un juez disidente logra influenciar el debate público, probablemente será debido a que la controversia tiene un grado relevante de desacuerdo en la sociedad. En consecuencia, una cuestión favorable podrá ser observada gracias al disidente: el mismo habría sido capaz de mejorar la calidad de la democracia ${ }^{81}$.

Sospecho que, en general, la comunidad no está muy interesada en conocer la composición de la mayoría cuando una decisión judicial es elaborada, y que probablemente este asunto solo interesará a un grupo muy específico de la elite. La relevancia del problema, entonces, se relaciona necesariamente con la capacidad que ese grupo tenga para influir al resto de la sociedad.

Asumiendo que existen diferentes facciones sociales que se expresan dentro de la elite conocedora de las disidencias, y asumiendo que dichas facciones normalmente no están de acuerdo en materias jurídico-morales, los desacuerdos judiciales, entonces, serán más representativos de esas diferentes posiciones. Así, los perdedores (aquella facción que no se ve representada por el voto mayoritario representado en la sentencia) podrán observar que su posición fue considerada en el debate judicial. Con la regla de la unanimidad forzada, en cambio, los desacuerdos sociales no se verán representados judicialmente y el debate público tendrá una diferencia importante con el debate jurídico que se da a conocer por parte de los tribunales. El problema de la legitimidad y aceptación, entonces, puede invertirse, especialmente en aquellos casos en que se espera que los tribunales resuelvan un problema que divide a la clase política. Por otra parte, si se considera que existen casos en que los políticos prefieren de-

81 Argumentos similares han sido elaborados por jueces y académicos norteamericanos, como Douglas (1948) 105, quien vincula las opiniones disidentes con la libertad de expresión; Nadelmann (1964) 276.; Brennan (1986) 437-438.; y también al profesor alemán Peter HäBERLE (2001) 180. 
jar la solución de ciertos problemas en manos de los jueces ${ }^{82}$, la decisión unánime puede traer grandes niveles de autoridad, la que crecerá aún más si la unanimidad es voluntaria, y no forzada. En efecto, la unanimidad forzada, al esconder el real nivel de apoyo judicial de la misma, podría ser considerada con menos respeto por los políticos que son contrarios a la sentencia. El gran problema de la regla de secreto es, en este sentido, que impide recibir los beneficios de la unanimidad voluntaria, al no permitir realizar distinciones entre una sentencia fuerte y una débil.

Veamos un ejemplo donde la unanimidad voluntaria ha producido resultados beneficiosos para la certeza jurídica. En Chile, hace algunos años, la ex Presidenta de la República Michelle Bachelet nombró a Carolina Tohá como ministra de Estado. Carolina Tohá era, a la fecha de la designación, diputada, habiendo sido elegida por la ciudadanía para representarla en el Congreso. El régimen presidencial chileno no admite compatibilidad de ambos cargos (ministro y diputado), cuestión que la Constitución reconoce. El partido político en el cual militaba Carolina Tohá designó a su reemplazante en la Cámara, sustituyendo la voluntad democrática de la ciudadanía por la voluntad de una cúpula partidaria. ¿Estaba permitido constitucionalmente que la Presidenta nombrara a una diputada como ministra, y que el partido político de esta última designara a su reemplazo?

Un grupo de abogados vinculados a la oposición al gobierno de Bachelet presentó un requerimiento ante el Tribunal Constitucional ${ }^{83}$. El caso no era fácil, ya que la Constitución no tiene una norma específica que resuelva el problema de manera directa, sino que varias reglas y principios que, operando en conjunto, podrían dar lugar a dos respuestas contradictorias. Curiosamente, el Tribunal Constitucional resolvió el problema de manera unánime ${ }^{84}$, señalando que el Presidente de la República no tiene ninguna prohibición para nombrar a un ministro que actualmente ejerce funciones como parlamentario, ya que este parlamentario cesa en sus funciones al momento en que es designado ministro ${ }^{85} 86$.

82 Ver Tushnet, Mark (2006) "The Supreme Court and the National Political Order: Collaboration and Confrontation". En Kahn, Ronald and Kersh, Ken (editores): The Supreme Court and American Political Development. $1^{a}$ edición. Kansas: Kansas University Press, pp. 117-138.

83 Nótese que ningún político de oposición participó en la presentación al Tribunal Constitucional. Todos los partícipes fueron abogados que no ostentaban, a esa fecha, cargos públicos ni de liderazgo en partidos políticos. La mayoría de ellos se asocia más bien a un mundo académico conservador, como ocurre con Miguel Otero y Eduardo Soto.

84 Hay un voto concurrente de los ministros Colombo, Fernández B. y Venegas, pero dicha prevención refuerza los argumentos de la mayoría.

85 Tribunal Constitucional. 9 de julio de 2009. Rol № 1357. Requerimiento para que se: "declare la inhabilidad constitucional de la diputada Carolina Tohá Morales para ejercer el cargo de Ministro de Estado y la elección de don Felipe Harboe Bascuñán como diputado reemplazante". Disponible en: http://www.tribunalconstitucional.cl/index.php/sentencias/ busca_home [fecha vista 14 de julio de 2011].

86 Véase un trabajo crítico: Núñez Poblete, Manuel A. (2010) "Sobre la designación como 
Todos los ministros (no importando sus posiciones habituales) favorecieron voluntariamente el poder del Presidente de la República; el deseo de los parlamentarios de tener la posibilidad de ascender en su carrera sin trabas relacionadas con la separación de funciones y la soberanía nacional; y el poder de los partidos políticos para reemplazar la voluntad soberana, perjudicando la democracia representativa y el control político que la ciudadanía ejerce sobre sus representantes. No hubo disidencias.

Un par de ańos después, el problema reapareció cuando el Presidente Piñera designó a cuatro senadores en ejercicio para servir como ministros de Estado ${ }^{87}$. No hubo, en estos casos, ninguna presentación al Tribunal Constitucional. Nadie alegó un eventual vicio de constitucionalidad en los nombramientos o en los reemplazos, sin perjuicio de que varias opiniones críticas se hayan invocado en el ámbito político. Ninguna de ellas, sin embargo, dudó de la juridicidad de lo sucedido ${ }^{88}$, ya que la doctrina unánime del caso Tohá había dado certeza acerca de lo que la Constitución dispone. Modificar la doctrina Tohá es, entonces, propio de una reforma constitucional y no de un litigio judicial. De esta manera, la decisión del Tribunal Constitución en el caso Tohá sirvió los propósitos del club transversal de los políticos.

La unanimidad sirvió para reforzar la autoridad de la sentencia y la voluntad de la elite política, siendo útil para legitimar la decisión judicial.

El ejemplo propuesto, es verdad, constituye un caso en que la justicia constitucional es útil para perjudicar el diseño democrático de nuestro sistema político. Sin embargo, también representa un caso ilustrativo acerca de la manera en que la unanimidad sirve para asentar doctrinas en casos difíciles. Aquí cabría preguntarse ¿qué hubiese sucedido si el Tribunal hubiese estado dividido? ¿La oposición al gobierno de Piñera hubiera organizado algún grupo para impugnar la designación de parlamentarios como ministros? ¿Se hablaría hoy de realizar una reforma constitucional o de dar una nueva batalla judicial ante el Tribunal Constitucional?

ministros de Estado de los parlamentarios en ejercicio. El fallo "Tohá" y el estatuto constitucional de los parlamentarios y los ministros de Estado dentro de nuestro sistema presidencial". En Fermandois, Arturo y Delaveau, Rodrigo (editores) Sentencias Destacadas 2009. Santiago, Ediciones Libertad y Desarrollo, pp. 97-116

87 Primero se trató de Andrés Allamand y de Evelyn Matthei, quienes asumieron como Ministros de Defensa y de Trabajo, respectivamente, y luego de Pablo Longueira y Andrés Chadwick, quienes fueron investidos como Ministros de Economía y Secretario General de Gobierno, respectivamente.

88 Véase, por ejemplo, la opinión de Sergio Bitar en su carta al Director de El Mercurio, 21 de julio de 2011; y la opinión de José Francisco García y Rodrigo Delaveau en su carta al Director de El Mercurio, 20 de julio de 2011. Ninguna de las dos cartas, que vienen de sectores opuestos con opiniones diferentes, cuestiona la juridicidad de los nombramientos. Ambas, por el contrario, llaman a una reforma constitucional para discutir el problema. 
El caso Tohá, al igual que el caso Brown ${ }^{89}$ en EE.UU. (al que ya me referí brevemente), son ejemplos acerca de cómo la unanimidad voluntaria puede fortalecer una decisión. Para que este beneficio opere, es necesario permitir que las cortes actúen de manera estratégica, admitiendo que sus integrantes pueden llegar a acuerdos de interés institucional para la corte. Con la unanimidad forzada (la regla del secreto), este beneficio desaparece por completo ya que los propios jueces no podrían enviar señales claras al sistema jurídico acerca de la fortaleza (o debilidad) de una decisión. La actitud estratégica de la corte puede ser utilizada con diversos propósitos, tales como la obtención de mayor legitimidad y la posibilidad de enviar señales a otras instituciones públicas de relevancia, con el objeto de defender el poder de la propia corte.

Cuando las cortes logran fortalecer su poder, ampliando su espacio dentro del sistema político, ellas normalmente logran resolver cuestiones profundamente controversiales, incluso con fuertes disidencias y en contra de gran parte de influyentes actores políticos. Así las cosas, la corte gana en independencia. Un ejemplo interesante lo constituye la Suprema Corte de los EE.UU., la que (luego de una larga historia) se ha ganado un espacio privilegiado dentro del sistema político norteamericano $y$, hoy, es capaz de enfrentar casos extremadamente difíciles sin hipotecar su independencia. Véase, por ejemplo, lo ocurrido en Bush v. Gore ${ }^{90}$, donde (en una sentencia adoptada con el apoyo de cinco jueces de un total de nueve) la Suprema Corte favoreció la pretensión del ex Presidente republicano George W. Bush, de salir electo en su segundo mandato, en contra del candidato demócrata Albert Gore, quien había obtenido mayores sufragios (aunque menos electores) en la elección presidencial del año 2000. La decisión fue muy controvertida a nivel de elite y produjo un alto impacto político y académico en los EE.UU. ${ }^{91}$, pero fue aceptada y respetada tanto por la comunidad como por las instituciones relacionadas, ya que la Corte "aparece haber ganado suficiente legitimidad como para 'salirse con la suya' con su decisión y hacer que ella sea respetada" 92 .

Brown v. Board of Education 347 U.S. 483 (1954).

Bush v. Gore 531 U.S. 98 (2000).

Solo a modo ilustrativo, la expresión Bush v. Gore (1) arroja 2.010 .000 de resultados en la búsqueda realizada a través de www.google.com; y (2) encuentra 146 trabajos académicos que usan dicha expresión en sus títulos, en la búsqueda por título que realicé en el buscador de la base de datos jurídica de Heinonline.

92 Gibson, James L., Caldeira, Gregory A. and Spence, Lester K. (2005). "Why do People Accept Public Policies they Oppose? Testing Legitimacy Theory with a Survey-Based Experiment". Political Research Quarterly, vol. 58, No 2, pp. 187. 
El hecho de que la sentencia tuviera una fuerte disidencia no afectó el capital político de la Corte ni afectó el cumplimiento de la misma ${ }^{93}$.

El cuarto supuesto (d) consiste en que la crítica que realiza una conexión entre sentencias divididas públicamente y aceptación debe ser demostrada de manera empírica. En este punto, los profesores Gibson, Caldeira y Spence, estudiando la aceptación de decisiones impopulares de la Suprema Corte de los EE.UU., han sugerido que las sentencias controvertidas (con disidencias publicadas) no necesariamente deslegitimizarán el resultado de las mismas ${ }^{94}$.

Sin embargo, lo que es aplicable a la Suprema Corte de los EE.UU. no es necesariamente aplicable a otros tribunales. Después de todo, la Corte norteamericana debe ser una de las más prestigiosas del mundo y tiene un largo recorrido en la historia política y constitucional de los EE.UU. Por eso, mayor evidencia proveniente de otros países será necesaria para obtener conclusiones más generales al respecto. La experiencia analizada, no obstante, sugiere que (al menos) es posible que en sistemas democráticos existan cortes divididas cuyas decisiones (populares o impopulares) sean obedecidas gracias al capital político de la institución. Como probablemente tratándose de cortes más jóvenes es necesario que las mismas construyan su capital político, permitirle a los jueces que actúen y voten de manera estratégica (como, por ejemplo, logrando la unanimidad voluntaria a través de la negociación) puede ayudar a la corte a fortalecer su poder. Sin perjuicio de lo anterior, no es del todo claro si la regla del secretismo es capaz de llegar a los mismos resultados, sobre todo si se considera que los países que admiten el secretismo, normalmente tienen al mismo tiempo una concepción disminuida del rol de los jueces que impide que estos sean responsables de dar una respuesta a los grandes problemas morales y políticos de una sociedad. Lo que sí puede afirmarse, es que el nivel de legitimidad de la Corte tiene algún efecto en la aceptación de sus sentencias ${ }^{95}$.

\section{(2.3) LA REGLA DE UNANIMIDAD TIENDE A MEJORAR LA CALIDAD DE LA (ARGUMENTACIÓN DE LA SENTENCIA}

Podría decirse que, como la regla de secretismo implica publicar un sentencia unánime, entonces las decisiones judiciales que se tomen nece-

\footnotetext{
93 De esta manera, el mismo Gibson comenta que "[c]on algunas excepciones, si una sentencia es consentida o dividida por partidismo parece tener pocas consecuencias de obediencia". Gibson (2005) 197.

94 "Muchos académicos creen que divisiones agudas en las decisiones de la Corte deslegitimizarán la orden contenida en la sentencia. Hemos encontrado poca evidencia que soporte esa creencia”. Gibson (2005) 197.

95 Véase otro trabajo relevante de Gibson, James L. (1989). "Understandings of Justice: Institutional Legitimacy, Procedural Justice, and Political Tolerance". Law \& Society Review, vol. 23, No 3, pp. 469-496.
} 
sariamente serán más consistentes con el estándar relativo a la eficiencia de Pareto (llamada óptimo de Pareto $\left.{ }^{96}\right)^{97}$.

Un ejemplo de lo anterior es lo que sucede con el sistema de jurados, quienes (normalmente actuando en materias penales) resuelven preguntas de hecho (¿culpable o inocente?) basados en la evidencia presentada. Los jurados están obligados a arribar a una decisión unánime sin la cual la función de los mismos no puede finalizar. Esta regla de unanimidad los obliga a alcanzar altos niveles de persuasión y deliberación con el objetivo de convencer a la minoría a sumarse a la mayoría. La minoría, no obstante, tiene poder de veto, ya que si ella no modifica su posición, el caso no puede resolverse. De esta manera, la decisión que se adopte tenderá a equilibrar todas las visiones en una perspectiva única ${ }^{98}$.

No obstante, el óptimo de Pareto (a) no tiene cabida en el contexto del secretismo, y (b) sí lo puede llegar a tener bajo la operatividad de la regla de transparencia judicial.

En efecto, cuando se prohíbe la publicación de las disidencias judiciales (a) no existe expectativa respecto a que la decisión será lograda gracias a la votación unánime de todos los miembros del tribunal. Ellos votan, se forma una mayoría, y a esa mayoría se le llama sentencia, la que

96 "Una transacción superior en el sentido de Pareto es aquella que mejora la posición de al menos una persona, sin empeorar la posición de nadie (...). En otras palabras, el criterio de la superioridad en el sentido de Pareto es la unanimidad de todas las personas afectadas". Posner, Richard A. (1998) El análisis económico del derecho. Traducción de Eduardo L. Suárez. $1^{a}$ edición. México, D.F: Editorial Fondo de Cultura Económica de México, pp. 19.

97 La unanimidad no solo ha sido utilizada como un estándar de eficiencia, sino que también como un estándar de justicia. Véase por ejemplo la manera en que John Rawls utiliza la unanimidad dentro de su tesis de la posición original (original position) y del velo de la ignorancia (veil of ignorance). Rawls, John (1999) The revised edition of "A theory of justice". Harvard, Boston: Harvard university press, pp. 139.

98 Un segundo ejemplo es lo que sucede cuando se fija una exigencia de supermayorías parlamentarias para aprobar proyectos de ley. Aun cuando estas reglas no exijan la unanimidad, ellas permiten recibir ciertos beneficios. Mientras la minoría tenga poder de veto sobre la mayoría, esta última no podrá imponer una ley que le sea perjudicial a esa minoría, por ejemplo, alterando las reglas del sistema electoral. Sobre este asunto, véase Verdugo R., Sergio (2009). "Regla de Mayoría y democracia: el caso de las leyes orgánicas constitucionales". Revista actualidad jurídica (Universidad del Desarrollo), No20, pp. 597-633. y García, José F. y Sото, Sebastián (2009). "Una Mirada Económica al Diseño Constitucional Chileno: Impacto sobre el proceso legislativo y acción de los grupos de interés". Latin American and Caribbean Law and Economics Association. Disponible en: http://escholarship.org/uc/item/09w90 4qs;jsessionid=B01EA71528EB2C9A9E1D8E9C71743BA4\#page-2, pp. 67. Además, las súper-mayorías incentivan la generación de bienes públicos por parte del proceso legislativo. GarCía (2009) 68-69.

Un tercer ejemplo, en Chile, lo representa la regla de quórum que la reforma constitucional de 2005 exige para que prospere la declaración de la inconstitucionalidad de un precepto legal con efectos permanentes y expansivos. Se exigen cuatro quintos (o sea, ocho de diez votos) para que pueda dictarse la sentencia derogatoria. Sobre esta materia véase Verdugo R., Sergio (2008) "La declaración de inconstitucionalidad de las leyes como control represivo abstracto". Revista Actualidad Jurídica (Universidad del Desarrollo), No 18, pp. 247-297. 
aparece como la única visión oficial. Así las cosas, la mayoría no se ve en la necesidad de intentar persuadir a la minoría a que se sume a su posición y, por consiguiente, no necesita revisar sus razones. En cambio, en el contexto de la regla de transparencia (b), como mostraré en la tercera sección de este trabajo, los profesores Cross, Tiller ${ }^{99}$ y Sunstein ${ }^{100}$ han demostrado de qué manera el disidente logra moderar las posiciones de la mayoría. Entonces, bajo la existencia de disidencias, la mayoría considera mejor a la minoría, mientras bajo la regla del secreto, la moderación no es necesaria porque las disidencias no pueden expresarse públicamente. Por esta razón, de ser cierto el argumento del óptimo paretiano, este operaría más hacia la inversa de lo que se pretende (favoreciendo la transparencia y no el secreto)

Como puede observarse, la eficiencia paretiana requiere de la unanimidad voluntaria, como ocurre cuando el sistema proporciona un poder de veto individual a cualquiera de los integrantes del jurado. Si los jueces están obligados a esconder sus votos y a adherir a la mayoría, el óptimo de Pareto no se alcanza, ya que la mayoría seguirá operando como mayoría.

Sin perjuicio de las ideas presentadas más arriba, es importante tener presente que la calidad de la deliberación no está necesariamente relacionada con la publicidad de los desacuerdos judiciales (aunque estos sí presionan por mejorar la calidad de la argumentación de la sentencia, como se verá en la sección tercera). En otras palabras, el modelo de disidencias no garantiza por sí solo un fortalecimiento en el debate interno. Es más, es posible encontrar elevados niveles de deliberación interna en contextos de secretismo, como ocurre con el sistema francés, donde los procedimientos demandan la participación de diversos actores, aun cuando sus posiciones no son finalmente publicadas ${ }^{101}$.

\section{(2.4) EL SISTEMA DE DISIDENCIAS INCREMENTA LA CARGA DE TRABA- JO DE LOS JUECES}

De acuerdo a esta crítica, el sistema de transparencia judicial genera una mayor carga de trabajo para los jueces, la que puede volverse excesi$\mathrm{va}^{102}$. Quienes le otorgan valor a este punto, podrían argumentar que los

\footnotetext{
99 Cross (1998).

100 Sunstein (2005) 166-185.

101 LASSER (2009) 40-41. "Como puede observarse fácilmente, los procedimientos de decisión judicial de las cortes superiores francesas son designados para generar un extenso debate judicial interno, el que, sin embargo, tradicionalmente aparece solo superficialmente en la sentencia judicial publicada”. LASSER (2009) 41.

102 La disidencia, podrían continuar los críticos, implica "gastar mucho tiempo y energía". PETERSON (1981) 428.
} 
jueces debieran utilizar su valioso tiempo en algo más útil ${ }^{103}$, ya que el costo alternativo de los jueces es bastante alto, sobre todo considerando que ellos son un recurso muy escaso ${ }^{104}$. Algunos de los autores que invocan esta crítica tienen en común una preocupación por el hecho de que las cortes no estén resolviendo el número de casos que debiera ${ }^{105}$.

Aunque una crítica como esta requiere de evidencia para demostrar su veracidad, asumiré (y concederé) que el hecho de que la carga de trabajo se incrementa debido a la existencia de votos particulares, solo con el objeto de plantear una respuesta: las disidencias son útiles, por lo que se justifica invertir recursos en ellas; y hay ciertas técnicas que se pueden emplear cuando los jueces se enfrentan a una excesiva carga de trabajo, como escribir disidencias más breves, contratar más asistentes, crear más cortes, etc. ${ }^{106}$. La pregunta correcta, entonces, es la siguiente: ¿es la disidencia lo suficientemente importante como para invertir en la implementación de alguna de estas técnicas? La respuesta a esta pregunta la dejaré para la sección siguiente, donde sintetizo los beneficios que se experimentan cuando se cuenta con un sistema de disidencias.

Mientras tanto, debiéramos hacernos otra pregunta: ¿cuál es el impacto en el trabajo de una corte cuando se adopta la política de terminar con las disidencias? En otras palabras, si se eligiera (por parte de jueces o legisladores) finalizar con la práctica de presentar los votos particulares públicamente y de dejar de escribirlos, para implementar un sistema de secretismo, ¿cuál sería la reacción de los jueces? ¿Dedicarían el tiempo que dejaron de utilizar en escribir votos particulares en otras funciones más indispensables?

Los jueces enfrentarían estas preguntas con tres respuestas alternativas: (a) revisarían más casos; (b) habría más tiempo para el ocio y el placer o se trabajaría más lenta y relajadamente; o (c) la Corte revisaría los

103 Después de todo, "cuando los jueces están ocupados, la primera cuestión que delegan es la redacción de sus opiniones. Posner, Richard A. (1993). "What do Judges and Justices Maximize? (The Same Thing Everybody Else)". Supreme Court Economic Review, vol. 3, pp. 26. Si esto es cierto, debiéramos cuestionar dos cosas: (a) si existe o no un problema con el hecho de que los jueces deleguen parte de su trabajo en sus asistentes (¿en qué grado?, ¿qué tipo de trabajo es delegable?); (b) si los jueces delegarían en cualquier caso, independiente de que exista o no un sistema de opiniones disidentes.

104 Solo hay 9 jueces en la Suprema Corte norteamericana y en el Consejo Constitucional francés; 12 magistrados en el Tribunal Constitucional español; 21 ministros en la Corte Suprema de Chile y 10 ministros en el Tribunal Constitucional chileno.

105 Véase, por ejemplo, a Pinna (2009) y Loth (2009) 270-271.

106 El juez Posner ha sugerido que los jueces cuentan con una suerte de aversión a presentar disidencias. Si ellos no tienen una preferencia fuerte respecto a una materia específica, es probable que ellos no escriban ninguna disidencia. Posner (2008) 33 y 50-51. Si Posner está en lo cierto, entonces el costo de disentir usualmente está relativizado por el hecho de que las disidencias son siempre voluntarias. Más adelante, Posner agrega que en la Corte Suprema los jueces son más propensos a escribir disidencias, entre otras razones, porque su carga de trabajo es más liviana. Posner (2008) 51. 
casos de manera más detenida, mejorando la calidad de la investigación y mejorando los argumentos de la decisión.

Es difícil predecir la respuesta que los jueces entregarían, aunque el modelo de comportamiento judicial que sugiere Posner indica que ellos probablemente maximizarían, entre otras cuestiones, su tiempo libre (cabe hacer presente que este modelo de Posner no se ha testeado empíricamente) ${ }^{107}$. Además, otro dato es la posición de Friedman et al., quien ha sugerido que una menor carga de trabajo no producirá necesariamente una mayor tasa de disidencias ${ }^{108}$.

En el siglo XIX, Thomas Jefferson mostraba una visión crítica de los jueces, por la cual la regla de unanimidad y secretismo es "(...) conveniente para el flojo, el modesto y el incompetente" ${ }^{109}$. Más evidencia es necesaria para determinar si Jefferson tiene razón o no ${ }^{110}$.

Una alternativa que es posible descartar es la que sostiene que si los jueces no tuvieran que escribir disidencias, entonces ellos dedicarían más tiempo a cada caso, presentando con ello mejores sentencias (c). En efecto, el secretismo normalmente debiera generar un resultado diferente a aumentar la calidad del trabajo. El ahorrar tiempo de los jueces probablemente produciría un razonamiento judicial más deficiente y una investigación más pobre ${ }^{111}$, ya que se perdería una las principales ventajas de la publicidad de las disidencias: aquella que presiona a la mayoría a fundamentar de mejor manera su posición, y aquella que sostiene que los disidentes tienen el potencial de moderar las posiciones de la mayoría, como se verá en la sección siguiente. Cabe hacer presente, no obstante, que tener una mejor calidad en el razonamiento judicial no significa necesariamente que exista un mayor nivel de deliberación y conversación entre los jueces. Lo anterior se debe a que existe una probable causa alternativa: el mayor trabajo que puedan realizar los asistentes de juez.

Otro argumento relacionado en contra del sistema de transparencia, indica que la disidencia promueve mayores niveles de litigación, fortale-

107 El juez Posner sugiere que el ocio y la disidencia están conectados en la opción del juez de pagar el costo por discrepar de los otros. Véase Posner (1993) 20. También reconoce la posibilidad de que el juez le "diga a sus amigos que se ha unido a una mayoría con la cual discrepa porque no pensó que el problema es lo suficientemente importante como para ordenar una opinión disidente". POSNER (1993) 23.

108 Friedman, et alii (1981) 789-791., lo que contrasta con la visión de Posner respecto de la Suprema Corte, indicada anteriormente.

109 Citado por Scalia (1994) 34.

110 Cass Sunstein ha proporcionado una perspectiva formal al problema revelado por Jefferson: económicamente, los conformistas pueden ser vistos como "free-riders, que se benefician de las acciones de otros sin agregar nada propio. (...) En contraste, los disidentes normalmente benefician a los demás, ofreciendo información e ideas de las cuales la comunidad ganará un buen trato". Sunstein (2005) 12.

111 Como dice el juez Scalia, "(...) el mayor porcentaje de las peores sentencias de mi Corte -no en su resultado sino que en su razonamiento- son las unánimes”. SCALIA (1994) 41. 
ciendo con ello el problema de la carga de trabajo excesiva ${ }^{112}$. Como las disidencias muestran que un problema legal está abierto a preguntas, entonces los posibles demandantes o apelantes encuentran una oportunidad para presentar nuevas acciones en el futuro (la disidencia es esperanzadora para ellos). De acuerdo a esta manera de razonar, la prohibición de publicar disidencias no resuelve necesariamente la pregunta jurídica, sino que solamente promueve menor litigación.

La capacidad de este argumento para hacer sentido depende de qué tan excesiva es la litigación que la disidencia promueve. Los actores del sistema pueden encontrar una buena oportunidad de cambiar una manera de interpretar el Derecho cuando observan que la composición de un tribunal se está modificando, o pueden ellos mismos obtener los elementos para convencer a los jueces de que cambien de posición. Cambiar el Derecho, como explicaré, es una virtud que el sistema de disidencias proporciona, y si la litigación excesiva es un costo real que el cambio del Derecho trae, entonces habría que preguntarse ¿en qué grado la tasa de acciones legales se elevará cuando se publica alguna disidencia? Si la tasa se aumentara significativamente, entonces este argumento debiera ser ponderado en conjunto con los beneficios que describiré en la sección siguiente.

\section{(2.5) LA UNANIMIDAD EVITA LA ANIMOSIDAD ENTRE LOS JUECES DE UN MISMO TRIBUNAL}

Según quienes sostienen este punto, la disidencia crea un clima hostil entre los jueces, originando tensión y un probable estrés. Sin embargo, la evidencia parece ser contradictoria ${ }^{113}$ y no permitiría extraer conclusiones empíricas sin observar mayores estudios ${ }^{114}$.

Si la animosidad existe (cuestión que probablemente variará mucho entre un tribunal y otro), es importante estudiar sus causa. Por supuesto, si las personas presentan constantes desacuerdos, algún grado normal de tensión se generará. Esto es normal y probablemente inevitable. Como ya señalé anteriormente, los jueces suelen tener opiniones diferentes entre ellos, al igual que los profesores de Derecho, los abogados, los estudiantes de Derecho, los políticos y los investigadores. ¿Cómo vamos a pedirles a los jueces que tengan consensos unánimes para todo? No sería realista.

112 Este argumento ha sido tratado por Evans (1938) 129 y Peterson (1981) 425, aunque Evans lo rechaza.

113 Aunque no es evidencia suficiente de nada, interesante es leer la opinión del juez Scalia, "Dudo si existen dos jueces que hayan disentido más regularmente el uno del otro, o más agudamente, que mi ex colega el juez William Brennan y yo. Yo siempre lo consideré, sin embargo, como uno de mis mejores amigos en la Corte, y pienso que el sentimiento era recíproco". Scalia (1994) 41.

114 Véase Peterson (1981) 428., quien compara diferentes estudios mostrando resultados contradictorios. 
Y si hay personas que están obligadas a trabajar juntas (jueces dentro de un tribunal colegiado), y ellas discrepan constantemente, es natural un cierto grado de rencor. La causa es el desacuerdo constante, y la regla de secretismo no es idónea para atacar esa causa, ya que ella solo esconde el desacuerdo, sin ser capaz de eliminarlo. No obstante, agregarle publicidad a un desacuerdo previo podría exacerbar una animadversión existente, sin ser su causa. Por otro lado jes la regla de secretismo capaz de mejorar el clima en que cual trabajan los jueces de un tribunal colegiado?

En conclusión, el argumento de la enemistad puede tener cierto valor si la evidencia demuestra que ella es producida por la publicidad de las disidencias y no por el solo hecho del desacuerdo (inevitable y común a cualquier sistema judicial). Si la animosidad existe, lo que es posible y probable, entonces debiéramos ponderar su importancia con las razones que examinaré en la sección siguiente.

\section{3) DEFENSA DEL SISTEMA DE OPINIONES DISIDENTES}

En esta sección argumentaré que los votos particulares (3.1) contribuyen a legitimar el rol de la Corte; (3.2) evitan el problema de accountability que se crea a través de la regla de secreto; (3.3) son útiles para colaborar con futuros (y normalmente positivos) cambios en el ordenamiento jurídico; (3.4) fortalecen la calidad del razonamiento del voto de mayoría; y (3.5) tiene un saludable efecto que modera la posición de la mayoría, aunque sin alterarla en el resultado ${ }^{115}$.

115 No trataré latamente el argumento por el cual las disidencias mejoran la independencia personal de los jueces (ya consideré el argumento de la independencia de la Corte, pero no de los jueces en particular). Podría pensarse que, el tener la posibilidad de presentar un voto separado de la mayoría, ello garantizaría su libertad para elegir la doctrina jurídica que cree correcta, fortaleciendo la independencia del juez. Véase, en general, Fernández (2009) 113. Este argumento no es completamente convincente, ya que la independencia parece más asociada a otras variables, tales como la inamovilidad, la autonomía presupuestaria, la existencia de remuneraciones estables, la ausencia de mecanismos de responsabilidad política, etc. Con lo anterior, un juez siempre puede mantener su independencia y elegir la alternativa que cree correcta en su votación, aun cuando pierda y su opinión sea ocultada. En los países donde se aplica la regla de secreto, los jueces igualmente son capaces de votar expresando sus posiciones de manera confidencial. El efecto positivo que la transparencia genera no es, entonces, el fortalecimiento de la independencia del juez, sino que el hecho de hacer esta independencia pública. Es cierto, no obstante, que dicha independencia será más conocida por la comunidad jurídica y que probablemente lo anterior representará un estímulo para que el juez (si valora el reconocimiento de su independencia) persista en sus posiciones. 


\section{(3.1) LAS DISIDENCIAS CONTRIBUYEN A LEGITIMAR EL ROL DE LA CORTE}

El sistema de opiniones o votos separados ayuda a legitimar la función de la Corte, básicamente porque es una señal de transparencia frente a la comunidad y a diferentes actores políticos, mediante la cual se entregan muestras relevantes de deliberación y debate judicial, y se dan a conocer los grupos que se forman entre los jueces que integran un mismo tribunal.

El profesor Lasser, comentando el secretismo francés, indica que el proceso de "decisión judicial del derecho civil (...) carece de una apropiada legitimidad precisamente porque carece de suficiente transparencia. Las sentencias judiciales del derecho civil consisten en un poco más que mandatos crípticos y técnicos"116. Por otra parte, el modelo de decisión judicial norteamericano trae, según Lasser, "gran legitimidad precisamente por su gran transparencia. Las opiniones firmadas individualmente (incluyendo prevenciones y disidencias), la publicidad de los votos judiciales, el directo reconocimiento de las dificultades interpretativas, la honesta discusión del desarrollo legal y judicial, y el público debate judicial sobre cuestiones sustantivas, se combinan para nutrir el accountability judicial y el control, para estimular el debate democrático y la deliberación, y en consecuencia para acordar una bien merecida legitimidad del Poder Judicial norteamericano"117.

Las palabras de Lasser parecen ser muy duras. En efecto, ellas necesitan ser puestas en perspectiva ya que, y como el propio autor citado reconoce $^{118}$ (y yo ya expliqué), las bases de la legitimidad judicial que

116 Lasser agrega que el proceso de decisión judicial francés "ofrece sentencias colegiadas monolíticas, sin firmar, que rehusan publicar los votos judiciales, prohibiendo las prevenciones y disidencias, y rehuye la abierta discusión de policy en favor de silogísticas -o al menos altamente deductivas- declaraciones que minimizan, sino enmascaran o ignoran, todo trabajo judicial interpretativo relevante". Lasser (2004) 4. Véase una respuesta en Pinna (2009), quien contesta recordando el problema del excesivo trabajo que ya analicé anteriormente. Para Pinna, la legitimidad de una corte se adquiere de mejor manera cuando el número de decisiones que ella entrega es más alto. Si la motivación de la sentencia no es tan "transparente", ello se debe a que la corte está intentando resolver todos los casos que llegan. El punto de Pinna favorece la Corte de Casación francesa y desfavorece la Suprema Corte de los EE.UU., ya que la primera acepta conocer y juzgar todos los casos que se encuentran dentro de su competencia, mientras la segunda selecciona de manera arbitraria los casos que va a conocer (a través del certiorari). Pinna agrega que los académicos franceses colaboran con el proceso de argumentación legal de manera separada, compensando de alguna manera la falta de discusión judicial. El argumento de Pinna, si bien se encuentra en un contexto en que la doctrina ocupa un lugar importante, no resuelve directamente el problema de transparencia planteado por Lasser. Una opinión similar a la de Pinna puede verse en Lотн (2009) 270-271.

117 LASSER (2004) 3-4.

118 LASSER (2009). 
un ordenamiento jurídico persigue no son necesariamente replicables en otros sistemas. Mientras el sistema norteamericano se basa en el debate y la transparencia, el francés aspira a la profesionalización jerárquica de su judicatura, donde los jueces sean obedientes y leales al legislador. El secretismo no es otra cosa, entonces, que una consecuencia de la "narrativa” que en que el sistema francés descansa. En consecuencia, la manera de medir la legitimidad debe ser diferente de un sistema a otro.

Si se prefiere, como lo hacen los EE.UU., medir la legitimidad con estándares de accountability, entonces el secretismo está en problemas. El problema radica en que existen muchos países (especialmente latinoamericanos) que, teniendo un sistema de votos particulares, ellos basan su narrativa en la herencia que han recibido de los países del derecho continental europeo. Esta combinación, en que la legitimidad se basa en un rol disminuido de los jueces y en la profesionalización de la justicia ${ }^{119}$, hace que la regla de transparencia judicial no opere con la misma fuerza que en los países anglosajones. Lo anterior no representa necesariamente una contradicción absoluta de tradiciones jurídicas al interior de un sistema judicial, sino que (todo lo contrario) entrega oportunidades para que el constitucionalismo (debido a su necesario vínculo con la transparencia, como ya se demostró) pueda desarrollarse de manera más profunda dentro de países que, al tener la tradición del derecho civil, no cuentan con una larga historia asociada al carácter normativo de la Constitución. En efecto, el constitucionalismo está cambiando el Derecho, sometiendo el poder del legislador a reglas que favorecen la protección de los derechos fundamentales. En este contexto, la transparencia judicial se puede combinar y desarrollar de manera exitosa, como ha ocurrido dentro del Tribunal Constitucional chileno, por ejemplo. No obstante, el modelo

119 En Chile por ejemplo, se suele considerar que los jueces no crean Derecho, sino que ellos solo son una suerte de esclavos de la ley. El sistema chileno opta por la profesionalización de su judicatura al tener una academia judicial y exigir que ciertos cargos judiciales importantes sean integrados por profesionales de carrera, cuidando la independencia de los jueces en el proceso de designación y entregándoles garantías durante su ejercicio (inamovilidad, remuneraciones estables, etc.). Nótese que lo anterior no ocurre tratándose del Tribunal Constitucional. El Código Civil chileno es, tal vez, la muestra más relevante de lo anterior. En efecto, el artículo 1 del mismo Código utiliza un concepto revolucionario de la ley, basada en la soberanía, donde la labor del legislador democrático se encuentra ensalzada. El artículo 3 limita el poder de los jueces al caso concreto que se resuelve mediante una sentencia específica, y reserva al legislador (democrático) el interpretar o explicar la ley de un modo general. El artículo 19, por su lado, marca una preferencia hacia el literalismo. Nótese que el Código Civil, en esta estructura básica, muestra una desconfianza hacia la labor del juez, donde se le pone bajo el legislador (no como contrapeso, sino que bajo su mando), quitándole poder y diciéndole cómo interpretar fielmente la ley bajo un sistema reglado. En este contexto, donde la narrativa chilena se parece a la francesa, existe también un sistema de disidencias abiertas y, por si fuera poco, un modelo de justicia constitucional amplio, con la participación de diversos actores (Contraloría, Tribunal Constitucional, Cortes de Apelaciones, etc.). 
de disidencias no será tan exitoso en aquellos tribunales que encuentren bajos niveles de fundamentación debido al exceso de trabajo con el que cuentan, como ocurre, por ejemplo, con las Cortes de Apelaciones cuando resuelven recursos de protección ${ }^{120}$.

La experiencia de los países del derecho civil que tienen una regla de transparencia y constitucionalismo, demuestra que existen buenas razones para medir la legitimidad de sus sistemas judiciales bajo un modelo mixto: uno que se acerque tanto al accountability como a la independencia judicial. ¿En qué medida ambos test de legitimidad se contraponen? Resulta ser una pregunta importante que postergaré por ahora.

Con la transparencia, la información acerca del comportamiento judicial se encuentra disponible para todos. El hecho de conocer lo que los jueces han hecho en el pasado, produce mayores niveles de predictibilidad en las decisiones que los mismos producirán en el futuro. Si dichas decisiones son más predecibles, entonces ellas serán más fáciles de aceptar ${ }^{121}$, lo que favorece especialmente la legitimidad de aquellas sentencias que resuelven materias controvertidas dentro de la sociedad. Es cierto que la transparencia no es el único elemento relevante cuando analizamos los niveles de aceptación social de una sentencia, pero es uno importante. Lo suficientemente importante como para promoverla.

Por otra parte, con el sistema de votos particulares la sentencia "(...) deja claro que la decisión fue producto de mentes independientes y consideradas, que intentan persuadirse una a la otra $(\ldots)$ "122. En ese sentido, la Corte gana en autoridad y respeto, beneficio que se hace más fuerte si la mayoría intenta contestar los argumentos presentados por los disidentes. Es aquí cuando la concepción democrática de las disidencias

120 Ilustrativas resultan las cifras entregadas por el propio Poder Judicial. En el año 2010, por ejemplo, ingresaron 35.649 causas a la Corte de Apelaciones de Santiago. Ese mismo año, se terminaron 32.544 causas dentro de la Corte. Así las cosas, no es de extrańar que la motivación de las sentencias no sea la mejor y, también, que el nivel de argumentación y el número de votos particulares sea probablemente bajo. Digo probablemente porque no existe la estadística de votos particulares a nivel de Cortes de Apelaciones. Véanse las estadísticas del Poder Judicial en http://www.poderjudicial.cl/modulos/Estadisticas/EST_Contexto. php?opc_menu=68xopc_item $=0$

121 Véase Muir, William Ker (1973) Law and Attitude change. 1 1a edición. Chicago: Chicago University Press, pp. 1-10 y pp. 111-138. Este autor realiza un caso de estudio en EE.UU., consistente en analizar la manera en que la sociedad (enfocado a una pequeńa localidad en su caso) acepta o no (y en qué nivel) una decisión judicial que no comparte. El estudio se enfocó en una controvertida sentencia de la Suprema Corte norteamericana que prohibió (por inconstitucionales) el ejercicio de ciertas prácticas religiosas dentro de las escuelas públicas. School District of Abington Township v. Schempp, 374 U.S. 203 (1963). En el caso de estudio de Muir, resultó importante la preparación social que las autoridades y la comunidad de la localidad tuvieron gracias a que la sentencia era esperada. Como había una alta probabilidad de que ella se dictara, la aceptación de la misma fue posible dentro de una comunidad que, según su perfil, se esperaba que resistiera más fuertemente.

122 SCAlia (1994) 35. 
se fortalece, siendo presentadas como ideas que compiten dentro del mercado (de las ideas) que operan dentro del ámbito de la Corte ${ }^{123}$.

El argumento de la legitimidad a través de la transparencia no está dirigido solo a la comunidad en general, sino que también a aquellos que se vieron perjudicados por una decisión judicial en un caso concreto. En efecto, una opinión disidente le dirá a quien haya sido desfavorecido por una sentencia "que su argumento fue escuchado y entendido", lo que le prepara mejor para aceptar el resultado adverso ${ }^{124}$.

\section{(3.2) EL SISTEMA DE DISIDENCIAS EVITA EL PROBLEMA DE ACCOUNTABILITY EXISTENTE CON EL SECRETISMO}

En el contexto del secretismo judicial, como es imposible saber con certeza la manera en que los jueces votan, no podemos evaluar el comportamiento de jueces individuales cuando estos integran un tribunal colegiado. La evaluación, necesariamente, caerá sobre el tribunal, no pudiendo separarse. De esta manera, los jueces se encuentran en una posición más protegida (e independiente, si se quiere) respecto de otras autoridades (un tribunal superior jerárquicamente, el Congreso, el Ejecutivo, entre otras) y de la comunidad en general. En consecuencia, cualquier mecanismo que intente hacer valer algún tipo de responsabilidad de los jueces de manera individual (ya sea por delito cometido al momento de votar, por evaluación hecha por el superior jerárquico, por acusación constitucional, por evaluación hecha por la prensa a propósito de alguna noticia de interés público ${ }^{125}$, entre otras) carecerá de la información suficiente para hacerlos realmente efectivos. Así, los frenos y contrapesos (checks and balances) operarán de manera deficiente

Asimismo, otros diseños institucionales se verían afectados debido a la asimetría de información que el secretismo produciría de existir. Así, por ejemplo, (a) el Senado no sabría de qué manera vota un juez del Tribunal Constitucional al que se presente designar nuevamente (no pudiendo evaluarlo con todas las herramientas del caso); (b) la Corte Suprema no conocería el comportamiento de algún juez de Corte de Apelaciones que se pretende integrar en una quina para proponerle al Presidente de la República un nombramiento para integrar la propia Corte Suprema; y (c) en el contexto de que exista un mecanismo de elección popular de jueces, como al interior de algunos Estados de EE.UU., la prensa y el electorado

\footnotetext{
123 Brennan (1986) 435. Véase también a Douglas (1948).

124 Fletcher (2009) 298. También, el juez Evans ha reconocido que las opiniones disidentes, para el lector y también para los litigantes, son "una prueba conclusiva de que las cuestiones presentadas fueron consideradas a fondo y seriamente (...)". Evans (1939) 129.

125 Así, el "[c]ontrol popular se debilita si las disidencias son ocultadas". Nadelmann (1959) 431.
} 
carecerían de información suficiente para apoyar a algún candidato que previamente ejerció funciones judiciales, entre varios otros ejemplos que podrían confeccionarse ${ }^{126}$.

Lo anterior es muy importante para el trabajo académico y la investigación respecto a la labor que desempeñan los jueces, ya que las opiniones disidentes son un buen input para los investigadores ${ }^{127}$. El debate público y científico se fortalece con la entrega de sofisticados trabajos. Si en la elaboración de dichos trabajos existe menos información disponible, entonces los mismos se verán afectados y la investigación será más costosa. Con el sistema de transparencia, en cambio, es más fácil recolectar la información que el sistema provee a los estudiosos ${ }^{128}$. No está de más recordar que tener la información correcta es fundamental para la confección e implementación de políticas públicas, incluso de aquellas que se vinculan con la judicatura.

\section{(3.3) EL SISTEMA DE DISIDENCIAS PUEDE CONTRIBUIR A CAMBIAR EL DERECHO EN EL FUTURO}

De acuerdo a este argumento, las disidencias son vistas como una interpretación alternativa del pasado que tiene la capacidad para influir en cambios futuros del Derecho (o de su interpretación, si se prefiere ${ }^{129}$. El cambio puede ser posible a través de la misma corte donde se presentó la disidencia, o en una diferente ${ }^{130}$. En el primer caso, por ejemplo, el Tribunal Constitucional modifica una posición sostenida en una discusión pasada, probablemente debido a un cambio en la composición del mismo tribunal o a un convencimiento de parte de algunos jueces de la mayoría por distinguir el caso nuevo respecto del asunto anteriormente tratado, realizando alguna precisión o una sofisticación de la doctrina que se contenía. En el segundo caso, por ejemplo, la Corte Suprema puede compartir la opinión del voto de minoría respecto de una sentencia dictada por una Corte de Apelaciones, y revertir el fallo de mayoría.

126 Un argumento similar ha sido hecho por el juez Brennan, quien cree que las opiniones disidentes "(...) salvaguardan la integridad del proceso de creación de sentencias al mantener a la mayoría rindiendo cuentas por el razonamiento y consecuencias de sus decisiones". BRENNAN (1986) 430.

127 En palabras del juez Evans: “Oh boy! ¡Cómo los profesores de Derecho aman las opiniones disidentes! (...) La unanimidad de los profesores de las Escuelas de Derecho en favor de las disidencias es mayor que la unanimidad de las opiniones mostradas por abogados y jueces en contra de las disidencias". Evans (1938) 127.

128 Humberto Nogueira parece compartir lo anterior cuando señala que las opiniones separadas constituyen un elemento de análisis para la comunidad jurídica. Nogueira (2005) 147.

129 Este argumento ha sido hecho por varios jueces y académicos norteamericanos como Cardozo (1939) 505; Pound (1953) 795; Stone (1943); 78, Sanders (1963) 676; y FLetCher (2009), entre muchos otros. También ha sido enunciado por el alemán HäberLe (2001) 180.

130 Peterson (1981) 427 
Aunque en general comparto este argumento, es importante tener presente que el Derecho (o la interpretación del Derecho) puede cambiar debido a causas independientes a una disidencia, aunque ella puede colaborar poniendo argumentos sobre la mesa y dándoles cierta autoridad al ser ellos sostenidos por jueces. Además, también es importante considerar que los cambios en el Derecho no son frecuentes. La cuestión, sin embargo, puede ser enfocada desde la importancia de los cambios que se han generado, y no necesariamente desde la cantidad. Es cierto que los cambios producidos cuando ha habido disidencias no son muy frecuentes, pero ellos efectivamente suceden, y existen algunos fundamentales para la protección de los derechos fundamentales de acuerdo a los cambios sociales que se han experimentado en el último siglo. Ejemplos abundan en los EE.UU. William A. Fletcher ha elaborado una lista de los que, a su juicio, son los casos más importantes, donde se ha generado lo que denomina como "efecto profético de las disidencias"131: (a) el voto particular de Harlan en Plessy v. Ferguson ${ }^{132}$, mediante la cual se argumentó en contra de la doctrina que defendía la diferencia racial en el principio de "separados pero iguales" (separate-but-equal doctrine), pese a dicha disidencia no provocaría un cambio real en varias décadas; (b) la disidencia de Holmes en in Lochner v. New York ${ }^{133}$, que defendió la prohibición estatal de que un empleador pudiera exigirle a un trabajador una jornada laboral de más de sesenta horas a la semana; (c) el voto separado de Holmes en Abrams $v$. United States ${ }^{134}$, donde sostuvo que no es un crimen que anarquistas distribuyan folletos durante la primera guerra mundial; (d) la opinión minoritaria de Brandeis en Olmstead $v$. United States ${ }^{135}$, donde se atacó la legalidad de pruebas obtenidas mediante escuchas telefónicas ilegales ${ }^{136}$. Además, puede invocarse el histórico casi citado Cardozo ${ }^{137}$, Dred Scott v. Sanford ${ }^{138}$, donde Curtis se negó a declarar que la esclavitud estaba protegida por el derecho de propiedad del amo.

Todas las disidencias citadas fueron muy importantes para la protección de los derechos fundamentales en los EE.UU., y entregaron a la comunidad la esperanza de que pudiera cambiarse la interpretación del Derecho por una más justa. En el lenguaje de Fletcher, el "efecto profético" contribuyó a proteger de mejor manera los derechos afectados en

\footnotetext{
131 Véase FLetCher (2009) 292-295.

132 Plessy v. Ferguson 163 U.S. 537 (1896). Brennan observe en la disidencia de Harlan una opinión profética que cruzó generaciones. BrenNan (1986) 432.

Lochner v. New York 198 U.S. 45 (1905).

Abrams v. United States 250 U.S. 616 (1919).

Olmstead v. United States 277 U.S. 438 (1928).

No incluyo el caso Baker v. Carr, ya que todavía es discutible si la disidencia de Frankfurter es o no Derecho válido (good law) hoy.

Cardozo (1939) 505.

Dred Scott v. Sandford 60 U.S. 393 (1857).
} 
el pasado. En contra de esto, podría decirse que a lo mejor los cambios se hubiesen producido igualmente sin la existencia de dichas disidencias, cuestión que nunca sabremos con certeza. Sin embargo, si se aceptara que los cambios igualmente se habrían producido, la disidencia aun habría tenido dos beneficios: (a) ella ayudó a instalar el debate y a mejorar la calidad de los argumentos del mismo desde que se cometió la infracción a los derechos fundamentales con el voto de mayoría ${ }^{139}$; (b) ella entregó mayor representatividad a quienes resultaron perjudicados por la decisión pasada que se modifica.

Otro argumento relacionado es el que proporciona Cass Sunstein, para quien la "disidencia puede captar la atención de la Corte Suprema y llevar a que una sentencia impugnada sea revertida; las decisiones de las cortes de apelaciones están más sujetas a una probable revisión si alguno de sus jueces presenta una disidencia. El disidente puede actuar como un denunciante" 140 . Este punto hace mucho sentido, ya que el disidente actúa denunciando una (mala o buena) interpretación del Derecho, haciendo notar a los jueces de un tribunal superior que, a lo menos, uno de los jueces que analizó el caso está en desacuerdo con la posición oficial del tribunal que dictó la sentencia impugnada ${ }^{141}$. Uno puede esperar que los jueces sean personas razonables y de experiencia, por lo que el voto particular entrega mayor autoridad (moral, si se quiere) a las acciones que impugnan el voto de mayoría. La fuerza de este argumento dependerá parcialmente del prestigio que tenga el juez que actúa como denunciante.

Es en este punto donde otra crítica a las opiniones disidentes, que ya enuncié anteriormente, puede hacer más sentido: si existen mejores chances de obtener que se revierta una sentencia impugnada cuando existe una disidencia, entonces será más probable que la tasa de impugnación de sentencias (y de litigiosidad a nivel de tribunales superiores), se incremente ${ }^{142}$. Esta crítica, sin embargo, adolece de una debilidad, ya que justamente lo que las políticas públicas en materia de justicia buscan, es que las impugnaciones que se presenten sean aquellas que se justifican y que, por consiguiente, valga la pena invertir recursos en su revisión. La disidencia puede operar como garantía de seriedad respecto de una acción de impugnación, advirtiendo a los jueces revisores que dicha acción se encuentra justificada (tenga o no razón). El sistema debiera desincentivar la presentación de acciones que no tienen fuertes motivaciones válidas, y debiera estimular la creación de mecanismos que permitan diferenciar

\footnotetext{
139 Incluso Robert Bennett, un fuerte crítico a lo que él denomina "disidencia individualista", parece suscribir este punto. Bennett (1991) 257-258.

140 Sunstein (2005) 180-181.

141 Un punto similar es compartido por el juez Scalia (1994) 36-37., para quien la disidencia opera como una "bandera de advertencia" para la Corte Suprema.

142 Peterson (1981) 426.
} 
una acción que presenta una buena motivación. El voto particular es uno de esos mecanismos.

Aunque este argumento no resulta aplicable a las opiniones minoritarias realizadas por ministros de la Corte Suprema ni del Tribunal Constitucional (por la imposibilidad de impugnar sus sentencias), su importancia resulta evidente.

\section{(3.4) LA DISIDENCIA TIENDE A FORTALECER EL RAZONAMIENTO DEL VOTO DE MAYORÍA}

Este argumento ha sido defendido por jueces que hablan desde su experiencia ${ }^{143}$. Mejorar la calidad de las sentencias de mayoría, como ya lo indiqué anteriormente, es el resultado de dos variables: (a) la existencia de discusión previa entre jueces de un mismo tribunal, o entre los jueces y los asistentes; y (b) la eventual existencia de un voto particular que presione a la mayoría a fundamentar de manera más acabada la sentencia. En este sentido, el disidente “(...) desafía el razonamiento de la mayoría, testeando su autoridad y estableciendo una un examen mediante el cual la fundamentación de la sentencia puede continuar siendo evaluada (...)" $)^{\prime 44}$.

Los beneficios de lo anterior, no obstante, pueden verse disminuidos en aquellos casos en que la mayoría ignora los argumentos de la minoría y evita contestarlos.

La deliberación (a), primera causa de que exista calidad en la sentencia, opera antes de que sea dictada la sentencia, mediante las razones presentadas durante el proceso y en la discusión existente entre los actores relevantes del tribunal ${ }^{145}$. La segunda causa (b), relativa a la existencia del voto particular, opera antes y después de la dictación de la misma. Antes, porque si la mayoría conoce argumentos de disidencias por adelantado (a través de los memos o discusiones internas) puede preparar las respuestas correspondientes. Después de la dictación de la sentencia, porque la mayoría puede intentar responder argumentos hechos por disidentes en casos similares ocurridos en el pasado. Si la composición relevante del tribunal cambia, entonces la nueva mayoría puede ser nutrida por disidencias anteriores.

Todas estas discusiones de ideas tienen el potencial de colaborar con más elementos de análisis para nutrir el debate público, lo que en parte dependerá del rol que asuman los medios de comunicación en monitorear la labor de los tribunales, de la capacidad de ciertos jueces para influir, la

\footnotetext{
143 Véase Brennan (1986) 430; Scalia (1994) 41 y Fletcher (2009) 296-297.

144 BrenNAN (1986) 435.

145 El "autor de la opinión mayoritaria debe responder las críticas contenidas en las disidencias y, en el proceso, mejorar esa opinión”. Peterson (1981) 427.
} 
cercanía que tenga la comunidad académica con la judicatura, entre otros factores.

Sin perjuicio de lo anterior, no puede desconocerse la importancia que existe para este punto el hecho de que los jueces que integran un mismo tribunal sean capaces de comunicarse entre sí. Que borradores sean compartidos, que las posiciones sean refinadas y que los asistentes participen de todos este proceso. Sin embargo, probablemente este hecho implica idealizar el trabajo de los jueces, ya que no existe claridad acerca de cuál es el real acercamiento que existe entre ellos. No obstante, sí es factible exigir algo que es verificable por parte de la comunidad: el hecho de que la mayoría reaccione frente a los votos particulares, y presente respuestas que garanticen el hecho de que, a lo menos, las posiciones minoritarias fueron conocidas. La mejor manera de descubrir la verdad, es hacer que las ideas compitan libremente, de manera que el resultado final pueda optimizarse ${ }^{146}$.

Además, es importante observar ciertas condiciones para que la visión judicial mayoritaria conozca posiciones diferentes y disidentes presentadas en sentencias anteriores. La primera de ellas es que exista la posibilidad de publicar los votos particulares. Una segunda es que los mismos sean estudiados por la comunidad jurídica, cuestión que ocurre más frecuentemente en la tradición anglosajona que en la del derecho civil, ya que en esta última no se le entrega un valor muy relevante al estudio de los votos particulares en la educación legal. En efecto, es poco frecuente que ellos sean citados en manuales y artículos científicos y que sean comentados en clases. Ello se debe a que la tradición continental europea se enfoca mayormente en los aportes que entregan prestigiosos profesores (como Arturo Alessandri R., por ejemplo) que en la interpretación judicial de la ley. Si a la comunidad jurídica no le interesan las opiniones disidentes, entonces es poco probable que las mismas sean capaces de fortalecer una sentencia futura. Aun así, sin embargo, la disidencia puede cumplir un rol relativamente significativo.

En cualquier caso, no debe asumirse que las sentencias judiciales son una fuente inútil dentro de la tradición del derecho civil, razón por la cual no puede descartarse de plano el hecho de que los casos son estudiados. Como señalan dos importantes comparativistas a propósito de la tradición del derecho civil, "aunque no existe una regla formal de stare decisis, la práctica de los jueces es verse influenciados por decisiones pasadas" ${ }^{147}$. Las sentencias judiciales son publicadas (aunque no siempre),

\footnotetext{
146 Véase la idea ya clásica de John Stuart Mill. Mill (1989) (1859) 48-49. Esta idea, conducente a la tesis del Mercado de las ideas, ha sido ampliamente difundida, aceptada y debatida en la doctrina y, también, en la jurisprudencia de la Suprema Corte de los EE.UU. Véase, como ejemplo, la famosa sentencia New York Times Co. v. Sullivan, 376 U.S. 254 (1964)

147 Merryman (2007) 47.
} 
los jueces suelen citar sentencias anteriores (aunque no siempre) y los abogados buscan casos pasados para realizar argumentos. Los comparativistas citados van mucho más allá: "El hecho de que las cortes en el derecho civil no actúen muy diferente en los reportes de las sentencias que se realiza en las cortes en los Estados Unidos (...) lleva a que la ausencia de una regla formal de stare decisis sea relativamente poco importante (...) todos saben que en las cortes del derecho civil se usan precedentes" 148 . A lo mejor esta aseveración va demasiado lejos, ya que en los países del derecho civil se trabaja mucho menos con sentencias, y la jurisprudencia constituye una fuente mucho menos importante que la legislativa y administrativa. Sin embargo, la opinión de los comparativistas citados es un ejemplo evidente de la manera en que algunos autores relativizan las diferencias existentes en ambas tradiciones. En suma, las sentencias importan en la tradición continental europea.

\section{(3.5) LAS DISIDENCIAS TIENEN UN SALUDABLE EFECTO MODERADOR DE LA MAYORÍA}

El hecho de existir un disidente dentro de un tribunal colegiado implica la existencia de una presión para que la mayoría aplique el Derecho en su sentencia, y no sus propias convicciones extrajurídicas. Además, se produce un efecto moderador de la doctrina jurídica que la mayoría invoca para fallar como falla, haciendo que ella evite los extremos ${ }^{149}$. Si este argumento es correcto, entonces el Estado de Derecho se fortalece gracias al disidente.

Frank B. Cross y Emerson H. Tiller han proporcionado evidencia demostrando que, en el sistema federal de tribunales colegiados en los EE.UU., al seguir el precedente del caso Chevron ${ }^{150}$, los disidentes producían un "efecto denuncia" (whistleblower effect) que hace que la mayoría fuera más proclive a seguir la doctrina legal establecida, y dejar de lado la mera inclinación ideológica ${ }^{151}$. Este efecto denuncia se produce cuando el panel de jueces se encuentra dividido, debido a que el disidente resulta ser una amenaza para quienes quieren imponer su propia visión extrajurídica.

148 Merryman (2007) 47.

149 Fletcher ha dicho, en un sentido similar, que la disidencia tiene el potencial de "mantener (o al menos de intentar mantener) a la mayoría honesta (...). El disidente puede en algunas ocasiones forzar a la mayoría a reconocer los hechos que van en contra del resultado favorable a la misma mayoría". Fletcher (2009) 297.

150 Chevron v. NRDC 467 (U.S. 837-1984) es un caso seminal del Derecho Administrativo norteamericano, que entrega deferencia a las determinaciones de las agencias (servicios públicos en general) cuando la ley bajo la cual se rigen no es clara en puntos específicos.

151 Cross (1998). El juez Richard Posner también ha opinado (aunque brevemente) sobre este punto, concluyendo que "los liberales moderan la mayoría conservadora, y los conservadores moderan la mayoría liberal”. Posner (2008) 33. 
En la presencia de un potencial "denunciante, la mayoría debe en ocasiones rendirse y mantener la decisión dentro de las fronteras de la doctrina jurídica"152. Cuando un panel está integrado por jueces de una misma tendencia política y moral, ellos "verán a la doctrina como un obstáculo más débil su capacidad para imponer sus creencias"153, y ellos probablemente tenderán a dictar sentencias más asociadas a posiciones extremas ${ }^{154}$. En otras palabras, cuando los jueces votan como equipo ideológico, sus posiciones se potencian y son más proclives a extremarse. Los resultados del estudio de Cross y Tiller demuestran que el denunciante "hace casi el doble de probable que la doctrina jurídica sea seguida cuando la doctrina trabaja en contra de una preferencia política de la mayoría de jueces" 155 .

Cass Sunstein coincide con los resultados del estudio de Cross y Tiller, sugiriendo una conclusión mucho más general, aplicable a diversas materias (no solo al caso Chevron): "los jueces son altamente vulnerables a la influencia de otro y un panel de tres jueces de similar tendencia tiende a llegar a los extremos"156. Para justificar su conclusión, Sunstein proporciona evidencia derivada de un seguimiento de casos de acoso sexual ${ }^{157}$ y también de casos medioambientales ${ }^{158}$. "La diversidad de visiones contribuye a corregir errores (...)"159, y la "existencia de jueces políticamente diversos, y el potencial de un disidente-denunciante, incrementa la probabilidad de que el Derecho sea seguido" 160 .

Un contraargumento puede ser proporcionado: aun cuando la evidencia demuestre que el efecto moderador del denunciante sea verdad, ello no considera que (a) todavía, existen cortes donde hay una sola visión doctrinaria, donde no existe ninguna posibilidad de disidencia (cuestión probablemente frecuente dentro de algunas salas de las Cortes de Apelaciones en Chile); y (b) los países que siguen la tradición del derecho civil en que las disidencias no son publicadas, también tienen disidencias (aunque ocultas). Si existen las disidencias, y aun cuando ellas no sean co-

152 Cross (1998) 2159.

153 Cross (1998) 2170.

154 Posner va más allá, diciendo que "las deliberaciones de jueces de similar tendencia produce una polarización del grupo, resultando en una sentencia más extrema que la opinión que los miembros de dicho grupo tenían antes de comenzar a deliberar". Posner (2008) 33.

155 Cross (1998) 2172.

156 Sunstein (2005) 166 y 168-169.

157 SunSTEIN (2005) 171.

158 Sunstein (2005) 172. Luego, Sunstein reconoce algunas excepciones donde las disidencias no son relevantes en producir un efecto moderador. No es dable imaginar este efecto en casos sumamente ideológicos donde existen profundas diferencias morales (pena de muerte, aborto). Probablemente en ese tipo de casos a la mayoría no le va a importar el efecto denuncia. Sunstein (2005) 183

159 Sunstein (2005) 177.

160 Sunstein (2005) 185. 
nocidas públicamente, no puede descartarse la posible capacidad que ellas tienen en influir y moderar a los jueces de la mayoría, aun en un contexto de secretismo.

El primer punto (a) es cierto. También lo es dentro de los países donde domina la regla del secreto. El problema no es, entonces, acerca de transparencia judicial. En cambio, el problema dice relación con la manera en que los jueces son designados y las garantías con que ellos cuentan para ser independientes. Este es un punto muy importante, pero escapa los objetivos de este trabajo.

El segundo punto (b) puede ser respondido fácilmente: en primer lugar, no es fácil obtener evidencia de parte de los países que utilizan la regla del secreto, ya que es sumamente difícil construir datos cuando no existe información relativa al comportamiento de los jueces en particular. En segundo lugar, puede ser cierto que el silencio y la disidencia oculta produzcan algún efecto independiente, pero probablemente dichos efectos son diferentes cuando se permite la publicidad de la "denuncia". La diferencia puede atribuirse al hecho de que la amenaza de una disidenciadenuncia es más fuerte cuando ella tiene el potencial de ser conocida por la comunidad. El disidente oculto solo puede intentar persuadir a los otros jueces, lo que puede resultar significativo, pero probablemente el impacto de ese intento de persuasión es significativamente menor a cuando se acusa públicamente a la mayoría de no seguir el (correcto o verdadero) Derecho. En estas condiciones, el efecto denuncia solo puede lograrse cuando la minoría tiene la facultad de escribir un voto separado.

\section{4) ¿Y SI SE ABUSA DE LA DISIDENCIA?}

Robert Bennet ha argumentado que, en la Suprema Corte de los EE.UU., los jueces han llegado muy lejos con el individualismo disidente $^{161}$. Él no es partidario de eliminar el sistema de disidencias, sino que de promover un mayor sentido institucional en la votación, algo que el autor vincula con el hecho de que deben obedecerse los precedentes pasados ${ }^{162}$. El problema de Bennet, entonces, no es sobre el voto particular, sino que sobre su uso ${ }^{163}$.

\footnotetext{
161 Bennett (1991).

162 "No me gustaría impedir el cambio en el Derecho o prohibir la disidencia. Como he sugerido, ambos pueden servir propósitos importantes. Pero la extensión de juzgar de manera individualista se ha tornado contraproducente, drenando la disidencia en su poder a través de su sobreuso, y poniendo en peligro no solo la estabilidad y la predictibilidad del derecho constitucional, sino su reclamo por respeto". BenNetT (1991) 1991.

163 Una idea similar ha sido expresada por el juez Evans, para quien las disidencias deberían bajar en número, y que él no ha podido reconciliar consigo mismo "una práctica que elimine o que incluso controle la opinión disidente”. Evans (1939) 135.
} 
Sin embargo, restringir de manera obligatoria el uso de la disidencia puede ser peor que el mal que se denuncia. ¿De qué manera concreta se propone reducirlo? En mi opinión, la mejor receta es permitir a los jueces tomar sus propias opciones, permitiéndoles negociar entre ellos para influir positivamente en su capacidad de autocontrol. Así podrán adquirir mejores herramientas para actuar de manera estratégica y, como ya se advirtió, puedan fortalecer el poder y la legitimidad de un tribunal dentro del sistema político. Una decisión judicial tomada unánimemente de manera voluntaria puede contribuir a promover ciertos valores relevantes. Por esta misma razón, el mismo Bennet llama a los jueces a producir un autocontrol basado en la "compañía de la mente y el hábito del pensamiento" 164 .

Es verdad que las tasas de disidencia en los países que tienen transparencia suelen ser altas a nivel de tribunales supremos. La Corte Suprema norteamericana, por ejemplo, entre 1789 y 1928, solo observó votos particulares en un $15 \%$ de los casos; entre 1930 y 1957 en un $42 \%$ de los casos; y en octubre de 1992 ellos se presentaron en un $71 \%$ de las sentencias ${ }^{165}$. Lo anterior demuestra que la Suprema Corte es altamente controversial o, tal vez, que en su composición existen algunos jueces individuales que son altamente diferentes a la mayoría ${ }^{166}$. El precedente vertical, no obstante, aún funciona, en general, entregando cierta certeza y predictibilidad a la comunidad.

En el caso del Tribunal Constitucional chileno ${ }^{167}$, la tasa de votos particulares entre agosto de 2006 y marzo de $2011^{168}$, fue de un $49,9 \%$ (263 sentencias presentaron votos separados de un total de 527$)^{169}$. ¿Significa lo anterior que en casi la mitad de los casos existe incerteza en el Derecho? ${ }^{170}$. Si la respuesta es afirmativa, entonces el Estado de Derecho chileno es bastante poco saludable. La respuesta, sin embargo, es negativa: la certeza está dada por la mayoría, y las disidencias colaboran anticipan-

164 BenNetT (1991) 259.

165 FLeTCHER (2009) 295

166 La cuestión en las Cortes Supremas estatales al interior de los EE.UU., es diferente, ya que la tasa de disidencias es mucho menos. Véase Friedman et alii (1981) 786-788.

167 Para un análisis del Tribunal Constitucional chileno, utilizando el modelo actitudinal, véase Carrol, Royce and Tiede, Lydia Brashear (2010). "Conflict on Chile's Constitutional Tribunal”. 5th Annual Conference on Empirical Legal Studies Paper. Disponible en: http://ssrn. com/abstract $=1630986$

168 Solo estoy considerando este periodo, porque desde la reforma constitucional de 2005, el Tribunal Constitucional cuenta con un Nuevo y diferente diseño institucional, el que no resulta comparable a los períodos anteriores.

169 Este número solo considera los casos resueltos por el Tribunal actuando en pleno. Además, se excluyeron tres casos: TC rol No 1288 (por su complejidad de materias); TC rol No 797 y rol Na 810 (por falta de información).

170 Es importante mencionar que no he proporcionado una tasa de disidencias en los países que utilizan la regla del secreto, ya que esa información no se encuentra, obviamente, disponible. 
do futuros posibles cambios debido a una eventual modificación en la integración del Tribunal. Una alta tasa de disidencias no significa necesariamente, entonces, la existencia de una inseguridad jurídica preocupante.

Cuando la tasa está muy alta no es fácil distinguir, sin embargo, cuáles son los votos particulares que producirán un "efecto profético" (en el lenguaje utilizado en la sección tercera), pero ello no significa que el mismo efecto se vea suprimido ${ }^{171}$. Los argumentos de certeza y transparencia todavía sobreviven, porque ellos no se ven afectados por el número de disidencias.

Por supuesto, si el caos se apodera de una corte presentando cambios de doctrina todos los días, el Estado de Derecho podría sufrir un daño significativo. Por lo mismo, el hecho de que la academia y la comunidad les exijan a los jueces una cierta consistencia individual con sus posiciones puede colaborar de manera relevante. Algunos diseños institucionales, por lo demás, pueden colaborar con la prevención de cambios muy frecuentes, tales como la garantía que tienen algunos jueces de servir en sus funciones de manera permanente e inamovible, de por vida (o con altos topes de edad), o la existencia de un modelo políticamente equilibrado de designación de jueces.

Las mayorías pueden cambiar. Y cuando lo hacen, probablemente ello sucederá en casos muy controvertidos donde disidencias pasadas se encuentran disponibles para su estudio por parte de la comunidad. Por consiguiente, un elemento de predicción se encuentra presente en los países que cuentan con una regla de transparencia, cuestión que evidentemente se ve fortalecida gracias al desarrollo de nuevas tecnologías en la búsqueda de jurisprudencia (West Law, Lexis Nexis, etc.). El problema radica en los países donde reina la regla del secretismo, ya que los cambios en el Derecho son más proclives a sorprender a la comunidad.

\section{5) CONCLUSIONES Y BASES PARA INVESTIGACIÓN FUTURA}

He argumentado que los sistemas legales que permiten la posibilidad de expresar disidencias judiciales públicamente, son más transparentes que otros sistemas jurídicos y, en consecuencia, son más proclives a legitimar la función de sus cortes. Con un sistema judicial abierto es posible, además, mejorar la calidad en la fundamentación de las sentencias, entregando mayor certeza acerca de lo que el Derecho (o su interpretación) es y de lo posiblemente será en el futuro. Además, he señalado que las disidencias tienen un efecto moderador de las posiciones de la mayoría cuando se trata de casos que no resultan demasiado controversiales. Así,

171 Fletcher (2009) 295. 
se logra que la doctrina jurídica tienda a imponerse sobre las opiniones extrajurídicas o ideológicas que ciertos jueces puedan querer llevar a cabo. Con lo anterior, las disidencias generan un Estado de Derecho más saludable. Por ello, he sugerido que aquellos países que aun cuentan con un sistema de secreto judicial, debieran estudiar la manera de adoptar una regla de transparencia.

Las razones entregadas no son, sin embargo, absolutas. Ellas necesitan ser balanceadas con aquellos argumentos que favorecen el establecimiento de la regla del secreto. He mostrado que hay que darle algún grado de importancia a tres cuestiones: (a) la ilusión de certeza que la regla de unanimidad entrega (especialmente a las elites), (b) el problema de la sobrecarga de trabajo, ya que la misma se puede ver afectada si los jueces escriben votos separados, y (c) la posibilidad de exacerbar la animosidad existente entre jueces de un mismo tribunal. Estos reclamos son relativamente válidos, pero poniéndolos en perspectiva con la regla de transparencia, ellos no son tan importantes. En efecto (a) la ilusión de certeza puede suprimirse con eventuales cambios en la composición del tribunal; (b) la sobrecarga de trabajo se incrementaría en ciertos países donde las sentencias tienen bajos niveles de fundamentación, aunque esta situación no afecta necesariamente a todos los países. Siempre existe la posibilidad de emplear técnicas judiciales (o más recursos) para enfrentar este efecto, y es útil invertir en esto debido al "efecto denuncia" que la disidencia genera moderando las posiciones de la mayoría dentro de un tribunal (y mejorando con ello nuestro Estado de Derecho) y con el hecho de que el razonamiento judicial mejorará, teniendo mayor potencial para contribuir al debate público y, finalmente, a la calidad de la democracia; (c) la posibilidad de exacerbar la animosidad entre los jueces no ha sido suficientemente demostrada, pero (de existir) ella podría afectar la labor de los jueces, aunque probablemente su causa se deba a la existencia de desacuerdos y no a la publicidad de los mismos, aunque evidentemente dicha publicidad pueda tener la fuerza de fortalecer la animosidad.

Los beneficios que la regla de transparencia otorga son importantes y ellos, al menos, justifican provocar que países que cuentan con sistemas de secreto judicial, evalúen la posibilidad de realizar cambios que consideren las particularidades propias de su tradición jurídica. No obstante, la recepción de la regla de transparencia por parte de tribunales internacionales y en algunas cortes constitucionales, unido al crecimiento del constitucionalismo, permite ser optimista frente a posibles cambios. Estas buenas noticias, sin embargo, no son absolutas, ya que la especial naturaleza de las materias internacionales y constitucionales es normalmente muy diferente respecto de otros temas jurídicos.

Es importante estudiar cómo trabajan los jueces dentro del contexto del secretismo, lo que representa un desafío importante atendido la falta de información disponible. ¿Cuentan con altos niveles de deliberación? 
¿Toman en cuenta argumentos de autoridades e instituciones relacionadas? ¿Tienen los disidentes una voz relevante dentro de un tribunal colegiado? ¿Produce el disidente un efecto moderador de la mayoría en el contexto del secretismo?

Todas estas preguntas encuentran un obstáculo empírico debido a la falta de información disponible, lo que obliga a los investigadores a emplear otros medios, más cualitativos, para entender lo que sucede dentro de las cortes que operan con secreto judicial.

Otro importante grupo de preguntas debe ser considerado para investigación y debate académico futuro: ¿cuán probable es que una cultura jurídica rechace los cambios propuestos? ¿Cuánto tiempo toma implementar esos cambios en una tradición que no está acostumbrada a que los jueces sean actores relevantes del debate democrático? ¿Cuál es el rol de la educación legal en la creación de una cultura jurídica más receptiva? ¿Es posible una implementación gradual de estas políticas? ¿Permitirán los políticos que este tipo de cambios opere, considerando que ellos significan observar a los jueces como actores significativos dentro del sistema político?

Este segundo grupo de preguntas son muy importantes de contestar, pero probablemente trabajar en ellas no es tan simple, ya que la creación de modelos teóricos que permitan testearlas requiere que nos pongamos de acuerdo en el diseño de estrategias de investigación multidisciplinarias. En este contexto, siempre habrá algún disidente que publicará una opinión en contrario. El consuelo es que ese disidente contribuirá a mejorar el trabajo académico...

\section{BIBLIOGRAFÍA}

Amram, Philip W. (1957). "The Dissenting Opinion Comes to the German Courts". The American Journal of Comparative Law, vol. 6, No 1, pp. 108-111.

Atria, Fernando (1993). "Tribunal Constitucional y Objeción Democrática". Revista Chilena de Derecho, vol. 20, No 2-3, pp. 367-378.

(2000) Revisión Judicial: el Sindrome de la Víctima Insatisfecha. Estudios Públicos, $\mathrm{N}^{\circ}$ 79. Disponible en: http://www. cepchile.cl/dms/lang_1/doc_1081.html

Bennett, Robert W. (1991). “A Dissent on Dissent". Judicature, vol. 74; No 5, pp. 255-260.

Brennan, William J. (1986). "In Defense of Dissents". The Hastings Law Journal, vol. 37, pp. 427-438.

Cámara Villar, Gregorio (1993). Votos particulares y derechos fundamentales en la práctica del Tribunal Constitucional Español: 1981-199. Madrid: Ministerio de Justicia, pp. 450. 
Cappelletti, Mauro, Merryman, John Henry, Perillo, Joseph M. (1965). The Italian Legal System. 1a edición. Stanford, California: Stanford University Press.

Cardozo, Benjamin N. (1939). "Law and Literature [comments]". Yale Law Journal, vol. 48, pp. 489-507

Carrol, Royce and Tiede, Lydia Brashear (2010). "Conflict on Chile's Constitutional Tribunal". 5th Annual Conference on Empirical Legal Studies Paper. Disponible en: http://ssrn.com/abstract=1630986

Correa, Rodrigo (2009): "Vulgarización por constitucionalización". Facultad de Derecho Universidad de Chile: Democracia y Derechos Fundamentales desde la Filosofía Política. Santiago: Editorial Jurídica de Chile, pp. 35-54.

Cross, Frank B. and Tiller, Emerson H. (1998). "Judicial Partisanship and Obedience to Legal Doctrine: Whistleblowing on the Federal Courts of Appeals". Yale Law Journal, vol. 107, pp. 2155-2176.

Douglas, William O. (1948). "The Dissent: A Safeguard of Democracy". Journal of the American Judicature Society, vol. 32, pp. 104-107.

Dworkin, Ronald (1985) A Matter of Principle. $1^{\text {a }}$ edición. New York: Oxford University Press, pp. 425.

Epstein, Lee, Segal, Jeffrey and Spaeth, Harold J. (2001). "The Norm of Consensus of the U.S. Supreme Court". American Journal of Political Science, vol. 45, pp. 362-377.

Epstein, Lee, Landes, William M. and Posner, Richard A. (2010). "Why (and When) Judges Dissent: A Theoretical and Empirical Analysis". U of Chicago Law \& Economics, Olin Working Paper No. 510. Disponible en: http://ssrn.com/abstract $=1542834$

Evans, Evans A. (1938). "The Dissenting Opinion. Its use and abuse". Missouri Law Review, vol. 3, pp. 120-142.

Favoreu, Louis Joseph (2001). "La Constitucionalización del Derecho". Revista de Derecho (Valdivia), vol. 12, no.1, pp. 31-43. Disponible en: http://mingaonline.uach.cl/pdf/revider/v12n1/art03.pdf

Fernández Segado, Francisco (2009). "La Recepción del Sondervotum en Alemania". Revista Iberoamericana de Derecho Procesal Constitucional, No 12, pp. 77-119.

Fletcher, George P., Sheppard, Steve (2005) American Law in a Global Context. $1^{\mathrm{a}}$ edición. New York: Oxford University Press, pp. 682.

Fletcher, William A. (2009) "Dissent". Golden Gate University Law Review, vol. 39, pp. 291-300.

Friedman, Lawrence, et alii (1981). "State Supreme Courts: A Century of Style and Citation”. Stanford Law Review, vol. 33, pp. 773-818.

García, José F. y Soto, Sebastián (2009). "Una Mirada Económica al Diseño Constitucional Chileno: Impacto sobre el proceso legislativo y acción de los grupos de interés". Latin American and Caribbean Law and Economics Association. Disponible en: http://escholarship.org/ 
uc/item/09w904qs;jsessionid=B01EA71528EB2C9A9E1D8E9C717 43BA4\#page-2, pp. 33-86.

Gibson, James L. (1989). "Understandings of Justice: Institutional Legitimacy, Procedural Justice, and Political Tolerance". Law \& Society Review, vol. 23, No 3, pp. 469-496.

Gibson, James L., Caldeira, Gregory A. and Spence, Lester K. (2005). "Why do People Accept Public Policies they Oppose? Testing Legitimacy Theory with a Survey-Based Experiment". Political Research Quarterly, vol. 58, No 2, pp. 187-201

Glenn, H. Patrick (2007) Legal Traditions of the World. 3a edición. New York: Oxford University Press, pp. 395.

Goutal, Jean Louis (1976). "Characteristics of Judicial Style in France, Britain and the U.S.A.". The American Journal of Comparative Law, vol. 24, pp. 43-72.

HäBerle, Peter (2001). "La Jurisdicción Constitucional institucionalizada en el Estado constitucional". Anuario iberoamericano de justicia constitucional, No 5, pp. 169-181.

Hart, H.L.A. (1961 y 1994) The Concept of Law. $1^{\text {a }}$ y $2^{\text {a }}$ edición. New York: Oxford University Press, pp. 262.

Klarman, Michael J. (2007) Brown V. Board of Education and the Civil Rights Movement. The abridged edition of "From Jim Crow to Civil Rights: The Supreme Court and The Struggle for Racial Equality". 2a edición. New York: Oxford University Press, pp. 284.

Kelsen, Hans (1994) Teoría pura del derecho. Introducción a la ciencia del derecho. Traducción de: Moisés Nilve. 28a edición. Buenos Aires: Editorial Universitaria de Buenos Aires, pp. 155-161.

Johnson, Charles A. (1979). "Lower Court Reactions to Supreme Court Decisions: A Quantitative Examination". American Journal of Political Science, Vol. 23, $\mathrm{No}^{\circ}$ 4: pp. 792-804.

Lasser, Michel (2004) Judicial Deliberations. A Comparative Analysis of Judicial Transparency and Legitimacy. 1 ${ }^{\text {a }}$ edición. New York: Oxford University Press, pp. 382

(2009). Transforming Deliberations. En Huls, Nick, Adams, Maurice, y Bomhoff, Jacco (editores): The Legitimacy of Highest Courts' Rulings. Judicial Deliberation and Beyond. $1^{\text {a }}$ edición. New York: Cambridge University Press, pp. 33-53.

Little, Rory (1999). "Reading Justice Brennan: Is There a "Right" to Dissent?” Hastings Law Journal, vol. 50, pp. 683-704

Loth, Marc A (2009) "Courts in a Quest for Legitimacy: a Comparative Approach". En Huls, Nick, Adams, Maurice, y Bomhoff, Jacco (editores): The Legitimacy of Highest Courts' Rulings. Judicial Deliberation and Beyond. $1^{\text {a }}$ edición. New York: Cambridge University Press, pp. 267-288. 
Lynch, Andrew (2004). "Is Judicial Dissent Constitutionally Protected?" Macquarie Law Journal, vol. 4, pp. 81-104.

(2004). "Taking Delight in Being Contrary, Worried about Being a Loner or Simply Indifferent: How do Judges really feel about Dissent?” Federal Law Review, vol. 32, pp. 311-329

Medina Rubio, Ricardo (2000) "La discrepancia en el seno del Tribunal Constitucional". Corts: Anuario de Derecho Parlamentario, N 9: pp. 305-306.

Merryman, John Henry and Perez-perdomo, Rogelio (2007) The Civil Law Tradition. An Introduction to the Legal Systems of Europe and Latin America. $3^{\text {a }}$ edición. Stanford, California: Stanford University Press, pp. 173.

Mill, John Stuart (1989) On liberty and other writings. Editado por Stefan Collini. $1^{\text {a }}$ edición (edición original 1859). New York: Cambridge University Press, pp. 289.

Muir, William Ker (1973) Law and Attitude change. $1^{\text {a }}$ edición. Chicago: Chicago University Press, pp. 170.

Nadelmann, Kurt H. (1959). "The Judicial Dissent. Publication v. Secrecy". The American Journal of Comparative Law, vol. 8: pp. 413432.

(1964). "Non-Disclosure of Dissents in Constitutional Courts: Italy and West Germany". The American Journal of Comparative Law, vol. 13, pp. 268-276.

Nogueira Alcalá, Humberto (2005) "La Integración y el Estatuto Jurídico del Tribunal Constitucional después de la Reforma Constitucional de 2005", Foro Constitucional Iberoamericano, No 11: pp. 136-148.

NúÑez Poblete, Manuel A. (2010) "Sobre la designación como ministros de Estado de los parlamentarios en ejercicio. El fallo "Tohá" y el estatuto constitucional de los parlamentarios y los ministros de Estado dentro de nuestro sistema presidencial". En Fermandois, Arturo, y Delaveau, Rodrigo (editores): Sentencias Destacadas 2009. Santiago, Ediciones Libertad y Desarrollo, pp. 97-116

Peterson, Steven A. (1981). "Dissent in American Courts". The Journal of Politics, vol. 43, No 2: pp. 412-434.

Pinna, Andrea (2009) "Filtering Applications, Number of Judgments delivered and Judicial Discourse by Supreme Courts: Some Thoughts Based on the French Example". En Huls, Nick, Adams, Maurice, y BомноғF, Jacco (editores): The Legitimacy of Highest Courts' Rulings. Judicial Deliberation and Beyond. $1^{\text {a }}$ edición. New York: Cambridge University Press, pp. 175-187.

Posner, Richard A. (1993). "What do Judges and Justices Maximize? (The Same Thing Everybody Else)". Supreme Court Economic Review, vol. 3, pp. 1-41. 
(1998) El análisis económico del derecho. Traducción de Eduardo L. Suárez. $1^{\text {a }}$ edición. México, D.F: Editorial Fondo de Cultura Económica de México, pp. 682

(2008) How Judges Think. $1^{\text {a }}$ edición. Harvard, Boston: Harvard University Press, pp. 387.

Pound, Roscoe (1953). "Cacoethes Dissentiendi: The Heated Judicial Dissent”. American Bar Association Journal, vol. 39, pp. 794-797.

Pritchett, C. Herman (1941). "Divisions of Opinion Among Justices of the US Supreme Court, 1939-1941". The American Political Science Review, vol.35, pp. 890-898.

Rawls, John (1999) The revised edition of "A theory of justice". Harvard, Boston: Harvard university press, pp. 607.

Rehnquist, William H. (1966). "The Supreme Court: The First Hundred Years Were the Hardest". University of Miami Law Review, vol. 42, pp. 475-490.

Ring, Kevin A. (2004) Scalia Dissents: Writings of the Supreme Court's Wittiest, most Outspoken Justice. $1^{\text {a }}$ edición. Washington DC: Regnery Publishing, Inc.

Rodríguez Grez, Pablo (1999) El derecho como creación colectiva. Santiago: Editorial Universidad del Desarrollo Ediciones Jurídicas, pp. 139-147.

Rousseau, Dominique (2002) La Justicia Constitucional en Europa. 2a edición. Madrid: Centro de Estudios Políticos y Constitucionales, pp. 110.

Sanders, Joe W. (1963). "The Role of Dissenting Opinions in Louisiana". Louisiana Law Review, vol. 23, pp. 673-679

Scalia, Antonin (1994). "The Dissenting Opinion". Journal of Supreme Court History, pp. 33-44.

Segal, Jeffrey A., Spaeth, Harold J. (1996). "The Influence of Stare Decisis on the Votes of United States Supreme Court Justices". American Journal of Political Science, vol.40, pp. 971-1003.

Schoenberger, Allen (2009). "Change in the European Civil Law Systems: infiltration of the Anglo-American Case Law system of Precedent into the Civil Law System". Loyola Law Review, vol. 55, pp. 5-21.

Squella Narducci, Agustín (2000) Introducción al derecho. $1^{a}$ edición. Santiago: Editorial Jurídica de Chile, pp. 576.

Stone, Harlan F. (1943). "Dissenting Opinions are not Without Value". Journal of the American Judicature Society, vol. 26, p. 78.

Sunstein, Cass (2005) Why Societies Need Dissent. $1^{a}$ edición. Harvard, Boston: Harvard University Press, pp. 246.

Tushnet, Mark (2006) "The Supreme Court and the National Political Order: Collaboration and Confrontation". En KaHN, Ronald and Kersh, Ken (editores): The Supreme Court and American Political 
Development. $1^{\text {a }}$ edición. Kansas: Kansas University Press, pp. 117-138.

Tushnet, Mark V. (editor) (2008) I Dissent: great Opposing Opinions in Landmark Supreme Court Cases. $1^{\text {a }}$ edición. Boston: Beacon Press, pp. 229.

Verdugo R., Sergio (2009). "Regla de Mayoría y democracia: el caso de las leyes orgánicas constitucionales". Revista actualidad jurídica (Universidad del Desarrollo), No 20, pp. 597-633.

(2008). "La declaración de inconstitucionalidad de las leyes como control represivo abstracto". Revista Actualidad Jurídica (Universidad del Desarrollo), No 18, pp. 247-297.

Waldron, Jeremy (2001) Law and Disagreement. $1^{\text {a }}$ edición. New York: Oxford University Press, pp. 344.

Williams Benavente, Jaime (1999) Lecciones de introducción al derecho. $3^{a}$ edición. Santiago: Editorial Ediciones Fundación de Ciencias Humanas, pp. 251 y 252.

Yarbrough, Tinsley E. (1992) John Marshall Harlan: great dissenter of the Warren Court. $1^{\text {a }}$ edición. New York: Oxford University Press, pp. 395.

Zapata Larraín, Patricio (2008) Justicia Constitucional. Teoría y práctica en el derecho chileno y comparado. Santiago: Editorial Jurídica, pp. 623. 